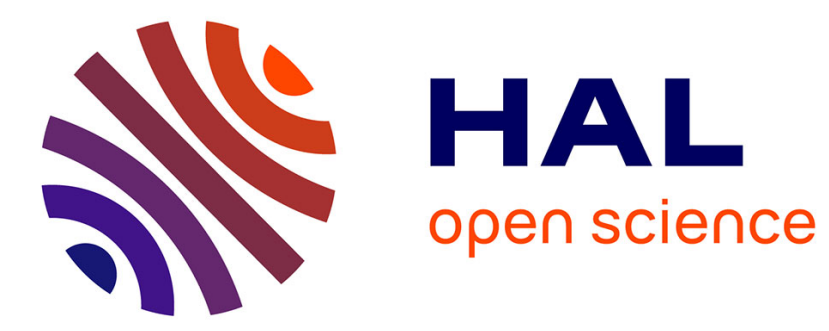

\title{
Two-stage partial melting during the Variscan extensional tectonics (Montagne Noire, France)
}

Marc Poujol, Pavel Pitra, Jean van den Driessche, Gilles Ruffet, Romain Tartèse, Jean-Louis Paquette, Jean-Charles Poilvet

\section{To cite this version:}

Marc Poujol, Pavel Pitra, Jean van den Driessche, Gilles Ruffet, Romain Tartèse, et al.. Two-stage partial melting during the Variscan extensional tectonics (Montagne Noire, France). International Journal of Earth Sciences, 2017, 106 (2), pp.477-500. 10.1007/s00531-016-1369-1 . insu-01341984

\section{HAL Id: insu-01341984 \\ https://hal-insu.archives-ouvertes.fr/insu-01341984}

Submitted on 11 Jul 2016

HAL is a multi-disciplinary open access archive for the deposit and dissemination of scientific research documents, whether they are published or not. The documents may come from teaching and research institutions in France or abroad, or from public or private research centers.
L'archive ouverte pluridisciplinaire HAL, est destinée au dépôt et à la diffusion de documents scientifiques de niveau recherche, publiés ou non, émanant des établissements d'enseignement et de recherche français ou étrangers, des laboratoires publics ou privés. 


\section{Two-stage partial melting during the Variscan extensional tectonics}

\section{2 (Montagne Noire, France)}

3 Marc Poujol ${ }^{\mathrm{a}, *}$, Pavel Pitra ${ }^{\mathrm{a}}$, Jean Van Den Driessche ${ }^{\mathrm{a}}$, Romain Tartèse ${ }^{\mathrm{b}, \mathrm{c}}$, Gilles Ruffet ${ }^{\mathrm{a}}$, Jean-

4 Louis Paquette ${ }^{\mathrm{d}}$, Jean-Charles Poilvet ${ }^{\mathrm{a}}$

$5 \quad{ }^{a}$ Géosciences Rennes, UMR CNRS 6118, OSUR, Université Rennes 1, 35042 Rennes CEDEX, France

6 ' Institut de Minéralogie, de Physique des Matériaux et de Cosmochimie, Muséum National d'Histoire Naturelle,

7 Sorbonne Universités, CNRS, UMPC \& IRD, 75005 Paris, France-France

$8 \quad{ }^{\mathrm{c}}$ Planetary and Space Sciences, The Open University, Walton Hall, Milton Keynes, MK7 6AA, United Kingdom

9 d UMR CNRS 6524, Laboratoire Magmas et Volcans, Université Blaise Pascal, 63038 Clermont-Ferrand CEDEX, 10 France

11 * Corresponding author. Tel.: +33-223236208. Email address: marc.poujo1@univ-rennes1.fr (M. POUJOL)

\section{ABSTRACT}

14 One of the striking features that characterise the late stages of the Variscan orogeny is the 15 development of gneiss and migmatite domes, as well as extensional Late Carboniferous and Permian sedimentary basins. It remains a matter of debate whether the formation of domes was related to the well documented late orogenic extension or to the contractional tectonics that preceded. Migmatization and magmatism are expected to predate extension if the domes are compression-related regional anticlines, but they must both precede and be contemporaneous with extension if they are extensional core complexes.

21 In the Montagne Noire area (southern French Massif Central), where migmatization, magmatism and the deformation framework are well documented, the age of the extensional event was unequivocally constrained to 300-290 Ma. Therefore, dating migmatization in this area is a key point for discriminating between the two hypotheses and understanding the Late

25 Palaeozoic evolution of this part of the Variscan belt. For this purpose, a migmatite and an associated anatectic granite from the Montagne Noire dome were dated by LA-ICP-MS (U- 
$27 \mathrm{Th} / \mathrm{Pb}$ on zircon and monazite) and laser probe ${ }^{40} \mathrm{Ar}-{ }^{39} \mathrm{Ar}(\mathrm{K}-\mathrm{Ar}$ on muscovite). Although 28 zircon did not record any Variscan age unequivocally related to compression (380-330Ma), 29 two age groups were identified from the monazite crystals. A first event, at ca. 319 Ma (U$\mathrm{Th} / \mathrm{Pb}$ on monazite), is interpreted as a first stage of migmatization and as the emplacement age of the granite, respectively. A second event at ca. 298-295 Ma, recorded by monazite (U$\mathrm{Th} / \mathrm{Pb}$ ) and by the muscovite ${ }^{40} \mathrm{Ar}-{ }^{39} \mathrm{Ar}$ system in the migmatite and in the granite, could be interpreted as a fluid-induced event, probably related to a second melting event identified through the syn-extensional emplacement of the nearby Montalet leucogranite ca. $295 \mathrm{Ma}$ ago. The ages of these two events post-date the Variscan compression and agree with an overall extensional context for the development of the Montagne Noire dome-shaped massif. Comparison of these results with published chemical (EPMA) dating of monazite from the same rocks demonstrates that the type of statistical treatment applied to EPMA data is crucial in order to resolve different monazite age populations.

Keywords: monazite, LA-ICP-MS, U-Th-Pb dating, muscovite, ${ }^{40} \mathrm{Ar}^{39}{ }^{39} \mathrm{Ar}$ dating, Variscan, Montagne Noire

\section{Introduction}

Until the late 1980s, wrench tectonics was considered to control the late Palaeozoic tectonic evolution of the Variscan orogen (Arthaud and Matte, 1977). It was interpreted as corresponding to an ultimate phase of N-S compression during the Late Carboniferous, and marked the end of the Variscan continental collision. In such compressive context, the commonly coal-bearing continental sedimentary basins that developed during the very late 
et al. 1989). The development of widespread continental sedimentary basins during the Permian was attributed to a subsequent pervasive N-S extension that occurred throughout the Variscan domain and was considered to result from a plate kinematics re-arrangement without any causal relation with the previous Variscan continental collision (e.g. Arthaud and Matte, 1977, Blès et al. 1989).

More recently, the late Palaeozoic tectonic evolution has been compared to extensional tectonics of both the Tibetan plateau and the North American Cordillera during the Cenozoic (e.g. Ménard and Molnar 1988; Burg et al. 1994). E-W extension, nearly parallel to the belt took place between 330-305 Ma during escape tectonics driven by still active N-S compression forces. It was followed by a NE-SW to N-S extension between $300 \mathrm{Ma}$ and 260 Ma, which started during the waning shortening, and implies a radical change in extension direction induced by the modification of the boundary conditions and the collapse of the entire chain after continental convergence (e.g. Burg et al. 1994). Both episodes of extension are viewed as a consequence of the previous N-S shortening, extension being induced by the collapse of the crust, considerably thickened during the continental collision, after thermal relaxation. In this interpretation, and contrary to older "compressive" interpretations, the late Carboniferous basins are extensional in origin as well as the Permian basins (Becq-Giraudon and Van Den Driessche 1993).

In both interpretations, the pervasive high-temperature low-pressure (HT-LP) metamorphism and magmatism that occurred throughout the Variscan chain during the late Carboniferous resulted from crustal thickening. A striking feature of this period was the development of gneiss and migmatite domes, such as those found in the Montagne Noire and the Velay areas in the southern part of the French Massif Central. However, the two interpretations disagree on the cause of their development. In the compressive scenario these structures are interpreted as regional anticlines that developed in response to the N-S 
shortening (Arthaud et al. 1966; Burg and Matte 1978; Matte et al., 1998), whereas they are interpreted as extensional gneiss domes, similar to the Cenozoic metamorphic core complexes of the Basin and Range province, in the extensional scenario (Van Den Driessche and Brun 1989, 1991; Echtler and Malavieille 1990; Brun and Van Den Driessche 1994). In the first case migmatization and magmatism predate extension. The second interpretation requires thermal relaxation and related rheological softening, and change in boundary conditions in order for the crust to collapse. Consequently, migmatization both precedes and is contemporaneous with the onset of extension, especially because extension can enhance partial melting by adiabatic decompression. In the Montagne Noire gneiss dome, the age of the extensional event was unequivocally constrained to ca. 295 Ma by dating a syntectonic leucogranite emplaced within the northward-dipping normal fault that bounds the gneiss dome to the north and controlled the development of Upper Carboniferous - Lower Permian sedimentary basins (Poilvet et al., 2011).

The Montagne Noire gneiss dome is a typical case where geochronology can yield critical constraints on tectonic models, and where the precision obtained on each individual age is crucial. This becomes even more important in a region that underwent a complex polyphased metamorphic/magmatic history possibly characterised by several phases of mineral growth (involving datable minerals such as zircon, monazite and muscovite) in a relatively short period of time. For the purpose of this study, two samples (a migmatite and an associated granite) from the Montagne Noire dome were selected for geochronological investigations ( $\mathrm{U}-\mathrm{Th}-\mathrm{Pb}$ on monazite and zircon and $\mathrm{K}-\mathrm{Ar}$ on muscovite), in order to discriminate between the two contradictory tectonic interpretations.

\section{Geological setting}


102 The Montagne Noire gneiss-migmatite massif is located in the southern French Massif

103 Central (Fig. 1). It is composed of a high-grade gneissic core surrounded by mostly low-grade

104 metasediments. The gneissic core is composed of migmatites and augen orthogneisses, with

105 some fine-grained gneissic intercalations that have been interpreted as either metasediments

106 or mylonitic zones (Bogdanoff et al. 1984; Van Den Driessche and Brun 1992, and references

107 therein). Some of these intercalations contain HP/HT mafic and ultramafic metamorphic

108 rocks, suggesting possible major early tectonic contacts (Bogdanoff et al. 1984; Allabouvette

109 and Demange 1993; Demange et al. 1995). The migmatites resulted mostly from partial

110 melting of sediments, but also of felsic augen orthogneisses (e.g. Bogdanoff et al. 1984;

111 Demange,1982). Weakly deformed to undeformed anatectic granites intrude both the

112 orthogneisses and the migmatites. The gneissic core is surrounded by weakly metamorphosed

113 or unmetamorphosed lower to middle Palaeozoic sediments that are intensely deformed by

114 southward verging folds and thrust faults (e.g. Arthaud 1970; Bogdanoff et al. 1984; Echtler

115 1990). Late Carboniferous to Early Permian detrital sediments uncomformably overlie these

116 tectonic units to the South. In contrast, to the North, the EW-trending north-dipping normal

117 fault zone (Espinouse detachment) marks the tectonic contact between these sediments and

118 the core units, and controls the development of the Lodève-Graissessac and Saint-Affrique

119 basins (Fig. 1; Van Den Driessche and Brun 1989, 1992; Burg et al. 1994).

120 The foliation of the gneissic core developed within the lower crust during the thrusting event

121 responsible for the deformation of the lower to middle Palaeozoic sedimentary cover. Its

122 dome-shaped structure and tectonic evolution is a matter of debate since long. Three types of

123 models have been proposed ranging from a diapir (e.g. Schuilling 1960; Faure and Cottereau

124 1988) a double megafold (Arthaud 1970; Burg and Matte 1978; Bogdanoff et al. 1984) or a

125 core complex (Van den Driessche and Brun 1989, Echtler and Malavielle 1990). Many recent

126 models combine in a more or less complex way the processes responsible for theses three 
types of structures to explain the final structure of the Montagne Noire: diapirism coeval with compression (Faure et al. 2010), compression and subsequent extension (e.g. Cassard et al., 1993; Franke et al. 2011, Doublier et al. 2015, Rabin et al. 2015), compression during extension (Rey et al. 2011), or compression, diapirim and extension (e.g. Soula et al. 2001, Charles et al. 2009). The precise structure of the Montagne Noire dome-shaped massif is beyond the scope of the present paper. We just note that structural and metamorphic analyses have not allowed to reach a consensus, although these different models are built from mostly similar (especially structural) data (e.g. Rey et al. 2011, Van Den Driessche and Pitra 2012). We conclude that until now, discriminating data are lacking to arbitrate between these models.

On the scale of the Variscan belt, the tectonic origin of the Montagne Noire massif is emblematic of the two end-member interpretations discussed before (i.e. compressive or extensive). Eventually, the two main questions are the timing of (1) the development of the HT-LP metamorphism, including partial melting, and (2) the initiation of the extensional tectonics, which predominates during Permian times.

Previous geochronological works on the protolith of the augen orthogneisses yielded Ordovician U-Pb zircon ages (456 \pm 3 for Pont-de-Larn, $450 \pm 6$ Ma for the Gorges d'Héric, Roger et al. 2004, 2015; $455 \pm 2$ Ma for the Saint-Eutrope gneiss, Pitra et al. 2012). According to Faure et al. (2010), migmatization took place between 333 and $326 \mathrm{Ma}$ (EPMA dating on monazite) while the emplacement of late anatectic granitoids took place between 325 and $316 \mathrm{Ma}$ (including the Vialais granite at $320 \pm 3 \mathrm{Ma}$ and Montalet leugranite at ca. 330 Ma, Fig. 1). However, a recent study by Roger et al. (2015) documented an emplacement age of ca $303 \mathrm{Ma}$ (U-Th-Pb on monazite) for the Vialais granite, while the Montalet leucogranite yielded monazite and zircon U-Th-Pb emplacement ages of ca $294 \mathrm{Ma}$ (Poilvet et al. 2011). 
152 Three monazite grains from the Gorges d'Héric orthogneiss yielded ${ }^{206} \mathrm{~Pb} /{ }^{238} \mathrm{U}$ ID-TIMS dates

153 around $310 \mathrm{Ma}$ interpreted as a metamorphic age (Roger et al. 2015). Franke et al. (2011)

154 reported a similar age of 313 Ma for monazite extracted from a foliated aplite dyke from the

155 Gorges d'Héric, while Maluski et al. (1991) reported a biotite K-Ar plateau age of $316 \pm 4$ Ma

156 for the Caroux massif. The undeformed garnet-bearing leucogranite of Ourtigas yielded a U-

$157 \mathrm{Th}-\mathrm{Pb}$ age of ca $298 \mathrm{Ma}$ (Roger et al. 2015). Finally, a monazite Th-Pb age of $294.4 \pm 4 \mathrm{Ma}$

158 (Pitra et al. 2012) as well as ${ }^{40} \mathrm{Ar}-{ }^{39} \mathrm{Ar}$ ages on muscovite and biotite of ca. $297 \mathrm{Ma}$ (Maluski

159 et al. 1991) have been obtained for orthogneiss samples sheared along the Espinouse

160 detachment.

162 3. Sampling and petrography

163

164 Two samples were selected for this study (Fig. 1): 1) a cordierite-bearing granite located in

165 the central part of the dome (sample ES7), and a migmatite (sample ES8), spatially associated

166 with the cordierite-bearing granite. Both rocks were sampled at the same locations as their

167 equivalent dated by Faure et al. (2010). One of the main reasons for this sampling strategy is

168 linked to the fact that previous dating (EPMA on monazite) by Faure et al. (2010) on the

169 Montalet granite returned an age $(327 \pm 7 \mathrm{Ma})$ that is very different from the age $(294 \pm 1 \mathrm{Ma}$;

170 U-Th-Pb on monazite) obtained by Poilvet et al. (2011) on the same granite. This age

171 difference was also noticed by Roger et al. (2015) for the Vialais granite. Therefore, the age

172 discrepancies cast some doubts on the EPMA ages obtained by Faure et al. (2010) on the

173 Laouzas cordierite-bearing granite and the spatially associated migmatite. They have also

174 been chosen because of the potentially complex history that these rocks underwent between

175340 and $290 \mathrm{Ma}$.

176 
The Laouzas granite (Fig. 1) crops out in the west-central part of the axial zone of the

Montagne Noire dome. It was sampled near the Laouzas dam $\left(43^{\circ} 38^{\prime} 7.35^{\prime \prime} \mathrm{N}, 2^{\circ} 45^{\prime} 10.00^{\prime \prime} \mathrm{E}\right)$.

The rock is an undeformed heterogeneous coarse-grained (1-5 $\mathrm{mm}$ in average, locally up to

$1823 \mathrm{~cm}$ ) biotite-bearing granite containing numerous large clusters of cordierite (up to $5 \mathrm{~cm}$ ),

183 biotite-rich schlieren, tourmaline nodules and dark, foliated mica-rich enclaves (Fig. 2a).

184 Although the schlieren and enclaves locally display a preferred orientation, no solid-state deformation is observed at the grain-scale in the granite, with the exception of a weak undulose extinction of quartz crystals. subordinate amounts of biotite, cordierite and muscovite (Fig. 2b). Dumortierite, tourmaline, andalusite and sillimanite are present locally. Plagioclase forms euhedral to subhedral stubby prismatic crystals, 1-3 mm long. Plagioclase cores are generally altered (saussuritised) and surrounded by a clear rim (Fig. 2c). The rims are similar to feldspar that also fills fractures in

192 the plagioclase cores. Some plagioclase rims are intergrown with tiny crystals of quartz in a 193 granophyric, myrmekite-like texture, in particular at the contact with K-feldspar. K-feldspar 194 and quartz are anhedral, 1-5 $\mathrm{mm}$ in size. Cordierite forms anhedral crystals (up to $2 \mathrm{~mm}$ ) that 195 are slightly pinitised or replaced by fine-grained muscovite around the rims (Fig. 2b). Biotite 196 crystals (0.1-3 mm) are subhedral and locally partly altered to chlorite in association with 197 needles of rutile (sagenite). Rare minute needles of sillimanite are locally present in large 198 quartz crystals. Although euhedral muscovite crystals $(\sim 1 \mathrm{~mm})$ are locally present, muscovite mostly forms large subhedral poikiloblasts (up to $2 \mathrm{~mm}$ ) or develops tiny crystals at the expense of K-feldspar, plagioclase or cordierite. Needles of dumortierite (pink to violet, 201 strongly pleochroic acicular crystals, $\sim 0.5 \mathrm{~mm}$ ) or tourmaline (pale green, $\sim 0.3 \mathrm{~mm}$ ) are 
commonly associated with clear plagioclase overgrowths, anhedral pink andalusite $(\sim 0.5 \mathrm{~mm})$ 203 and muscovite (Fig. 2c).

These observations suggest a two-stage evolution. The crystallisation of the relatively coarse-grained granite (plagioclase cores, K-feldspar, quartz, biotite, cordierite, \pm muscovite

$206 \pm$ sillimanite) was followed by a second event resulting in the crystallisation of the plagioclase 207 rims, dumortierite, tourmaline, andalusite and muscovite. The second stage was possibly 208 associated with the alteration of the plagioclase cores and biotite. It could be either magmatic 209 or, more probably, hydrothermal in origin. The hydrothermal origin is supported by the 210 textures and in particular the position of the boron-bearing minerals. Indeed, tourmaline and 211 dumortierite are known to be related to hydrothermal alteration (e.g. Taner and Martin, 1993), 212 but are liquidus rather than late-stage phases in leucogranitic magmatic systems (Benard et 213 al., 1985).

\subsection{La Salvetat migmatite, sample ES8}

217 The La Salvetat migmatite crops out in the central part of the axial zone of the Montagne 218 Noire gneiss dome, generally to the south of the Laouzas granite (Fig. 1). It was sampled ca. $2192 \mathrm{~km}$ south of the Laouzas dam, close to the summit of a hill called Al Rec del Bosc $220\left(43^{\circ} 37^{\prime} 1.65^{\prime \prime} \mathrm{N}, 2^{\circ} 45^{\prime} 23.70^{\prime \prime} \mathrm{E}\right)$. The rock is a banded stromatic migmatite (Fig. $\left.2 \mathrm{~d}\right)$ and is 221 locally garnet-bearing. The foliation is defined by a weak preferred orientation of biotite that 222 is parallel to alternating layers of leucosome, mesosome and biotite-dominated melanosome. 223 Leucosomes are relatively coarse-grained $(0.5-3 \mathrm{~mm})$, up to $1 \mathrm{~cm}$ thick, and are composed of 224 subhedral plagioclase, quartz and subordinate K-feldspar, and locally contain cordierite, 225 muscovite, biotite and tourmaline (Fig. 2e). Tourmaline commonly forms anhedral to 226 subhedral interstitial, optically zoned grains. Plagioclase and K-feldspar have a dusty 
appearance and plagioclase is partly replaced by zoisite/clinozoisite and white mica (Fig. 2f).

228 Cordierite is subhedral and partly altered to pinite. Biotite is locally partly replaced by 229 chlorite and contains lenses of minute prehnite (?) or clay minerals that are parallel to the 230 (001) cleavage (Fig. 2f), in particular in the leucosome and in the adjacent melanosome.

231 Euhedral muscovite is locally present in the leucosome. Subhedral muscovite, forming either

232 fine-grained clusters or larger poikilitic crystals, commonly develops at the expense of biotite, 233 cordierite and feldspars in the leucosomes.

234 These observations suggest at least two stages of evolution, where the migmatite 235 textures, attributable to partial melting, are partly overprinted by hydrothermal alteration. The 236 geographic proximity and the common petrographic character of the leucosomes and the 237 Laouzas granite suggest a genetic relation between the two. Therefore, the La Salvetat 238 migmatite is interpreted to be a likely source for the anatectic Laouzas granite.

\section{U-Th-Pb LA-ICP-MS and ${ }^{40} \mathrm{Ar}-{ }^{39} \mathrm{Ar}$ dating}

\subsection{Analytical techniques}

\section{4.1.1 NanoSIMS analytical protocol}

244 The distribution of selected species was imaged in some monazite grains using the NanoSIMS 24550 ion probe at the University of Rennes 1 . Secondary ion images of ${ }^{89} \mathrm{Y},{ }^{139} \mathrm{La},{ }^{140} \mathrm{Ce},{ }^{149} \mathrm{Sm}$, $246{ }^{206} \mathrm{~Pb},{ }^{208} \mathrm{~Pb},{ }^{232} \mathrm{Th}$ and ${ }^{238} \mathrm{U}^{16} \mathrm{O}$ were collected using the same primary O- beam of $\sim 170 \mathrm{pA}$ 247 over $90 \mu \mathrm{m} \times 90 \mu \mathrm{m}$ areas. The mass resolving power was set to $\sim 3500$, sufficient to readily 248 resolve isobaric interferences such as ${ }^{143,145} \mathrm{NdPO}_{2}$ on ${ }^{206,208} \mathrm{~Pb}$. A single plane of image data, 249 divided in $128 \mathrm{px} \times 128$ pixels, was collected using a dwell time of $40 \mathrm{~ms} /$ pixel, representing 250 an acquisition time of $\sim 11 \mathrm{~min}$ for each area. The raw image data were processed using the 
L’image (Larry Nittler, Carnegie Institute of Washington, USA;

252 http://home.dtm.ciw.edu/users/nittler/limage/limage_manual.pdf) and ImageJ softwares.

\subsubsection{U-Th-Pb dating technique}

255

256

257

A classic mineral separation procedure has been applied to concentrate minerals suitable for U-Th-Pb dating using the facilities available at Géosciences Rennes (see Poilvet et al., 2011). Zircon and monazite grains were carefully handpicked under a binocular microscope and embedded in epoxy mounts. The grains were then polished on a lap wheel with a $6 \mu \mathrm{m}$ and 1 $\mu \mathrm{m}$ diamond suspension successively. Zircon grains were imaged by cathodoluminescence (CL) using a Reliotron CL system equipped with a digital colour camera available in Géosciences Rennes and monazite grains by backscattered electron imaging on a JEOL JSM 6400 as well as by NanoSIMS. In addition, monazite grains have also been identified in thin sections in order to date them in context.

$$
\mathrm{U}-\mathrm{Th}-\mathrm{Pb} \text { geochronology of zircon and monazite was conducted by in situ laser }
$$
ablation inductively coupled plasma mass spectrometry (LA-ICP-MS) at the Laboratoire Magmas et Volcans in Clermont-Ferrand, France. Ablation spot diameters of $26 \mu \mathrm{m}$ and $7 \mu \mathrm{m}$ with repetition rates of $3 \mathrm{~Hz}$ and $1 \mathrm{~Hz}$ were used for zircon and monazite, respectively. Data were corrected for $\mathrm{U}-\mathrm{Pb}$ and $\mathrm{Th}-\mathrm{Pb}$ fractionation and for the mass bias by standard bracketing with repeated measurements of the 91500 zircon (Wiedenbeck et al. 1995) or the Moacyr monazite standards (Gasquet et al. 2010). Repeated analyses of GJ-1 zircon $(607 \pm 15$ Ma, N=6; Jackson et al. 2004) or Manangoutry monazite (554 \pm 23 Ma, N=6; Paquette and Tiepolo 2007) standards treated as unknowns were used to control the reproducibility and accuracy of the corrections. Data reduction was carried out with the GLITTER ${ }^{\circledR}$ software package developed by the Macquarie Research Ltd. (Jackson et al. 2004). Concordia ages and diagrams were generated using Isoplot/Ex (Ludwig 2001). All errors given in Table 1 and 2 
are listed at one sigma, but where data are combined for regression analysis or to calculate

277 weighted means, the final results are provided with 95\% confidence limits. Further

278 information on the instrumentation and the analytical technique is detailed in Hurai et al.

279 (2010).

For each grain analyzed (zircon and monazite) we also estimated the concentrations of

$281 \mathrm{U}, \mathrm{Th}$ and $\mathrm{Pb}$ as follows. First, the drift factor was calculated using the parameter $\mathrm{a}$ and $\mathrm{b}$ of a 282 linear regression of the average ${ }^{206} \mathrm{~Pb}$ counts per second (cps) for all the standards measured 283 during the course of the analyses as a function of their position during the acquisition.

(1) ${ }^{206} \mathrm{~Pb}_{\mathrm{cps}}=\mathrm{a} \times \mathrm{N}+\mathrm{b}$ with ${ }^{206} \mathrm{~Pb}_{\mathrm{cps}}=$ average measured values for the standard in cps corrected from the blank, $\mathrm{a}=$ 286 slope of the regression, $\mathrm{b}=$ ordinate at origin and $\mathrm{N}=$ analysis number.

287 The drift factor for each analysis $\left(D F^{N}\right)$ is then calculated as follows:

$$
\text { (2) } D F^{N}=\frac{b}{(a \times N+b)}
$$

Then the $\mathrm{Pb}$, Th and $\mathrm{U}$ concentrations are calculated using the known concentrations of these elements in the standards following:

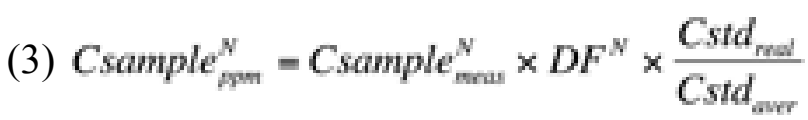

292 with $\mathrm{N}=$ analysis number, Csample $e_{p p m}^{N}=$ calculated concentration of the element in ppm, 293 Csample $e_{\text {mes }}^{N}=$ measured values of the element in cps, $D F^{N}=$ drift factor calculated for this 294 analysis, $C s t d_{\text {real }}=$ known concentration of the standard and $C s t d_{\text {aver }}=$ drift-corrected average 295 value for all the standards measured during the course of the analyses.

\subsubsection{Ar-Ar dating technique}

298 Single grains of muscovite used for the experiments were handpicked under a binocular 299 microscope from $0.25-1.00 \mathrm{~mm}$ fractions of crushed rock samples. Care was taken to select 
inclusion-free crystals of about $1 \mathrm{~mm}$ in size, in order to avoid large poikilitic crystals as well 301 as fine-grained clusters.

The samples were wrapped in $\mathrm{Al}$ foil to form small packets $(11 \times 11 \mathrm{~mm})$ that were stacked up to form a pile within which packets of fluence monitors were inserted every 10

304 samples. Irradiation was performed at the HFR Petten reactor (Petten, the Netherlands) in the 305 Cd-shielded Rodeo P3 facility and lasted $72 \mathrm{~h}\left(\mathrm{~J} / \mathrm{h} \approx 2.54 \times 10^{-4} \mathrm{~h}^{-1}\right)$. The irradiation standard 306 was amphibole Hb3gr (Turner et al. 1971; Roddick 1983, Jourdan et al. 2006; Jourdan and 307 Renne 2007), with an age of $1081.0 \pm 1.2 \mathrm{Ma}$ (Renne et al. 2010, 2011).

308 Step-heating analyses of single grains were performed with a $\mathrm{CO}_{2}$ laser probe coupled 309 to a Map215® mass spectrometer. The experimental procedure is described in Ruffet et al. 310 (1991) and Ruffet et al. (1995). The five argon isotopes and the background baselines were 311 measured in eleven cycles, in peak-jumping mode. Blanks were performed routinely each first 312 or third/fourth run, and subtracted from the subsequent sample gas fractions. All isotopic 313 measurements are corrected for $\mathrm{K}, \mathrm{Ca}$ and $\mathrm{Cl}$ isotopic interferences, mass discrimination and 314 atmospheric argon contamination. Apparent age errors are plotted at the $1 \sigma$ level and do not 315 include the errors on the ${ }^{40} \mathrm{Ar}^{*}{ }^{39} \mathrm{Ar}_{\mathrm{K}}$ ratio and age of the monitor and decay constant. The 316 errors on the ${ }^{40} \mathrm{Ar}^{*} /{ }^{39} \mathrm{Ar}_{\mathrm{K}}$ ratio and age of the monitor and decay constant are included in the 317 final calculation of the (pseudo-)plateau age error margins or for apparent ages individually 318 cited. Details on the method and ${ }^{40} \mathrm{Ar} /{ }^{39} \mathrm{Ar}$ analytical data are given in the Supporting 319 Information.

320 It is commonly considered that a plateau is obtained when calculated ${ }^{40} \mathrm{Ar}^{*} /{ }^{39} \mathrm{Ar}_{\mathrm{K}}$ 321 ratios of at least three consecutive steps, containing a minimum of $70 \%$ of the ${ }^{39} \mathrm{Ar}$ released, 322 agree with the weighted mean calculated ${ }^{40} \mathrm{Ar}^{*}{ }^{39} \mathrm{Ar}_{\mathrm{K}}$ ratio of the plateau segment. Pseudo323 plateau ages can be defined with less than $70 \%$ of the ${ }^{39}$ Ar released. All ages are displayed at 324 the $1 \sigma$ level. Analytical data, parameters used for calculations (isotopic ratios measured on K, 
$325 \mathrm{Ca}$ and $\mathrm{Cl}$ pure salts; mass discrimination; atmospheric argon ratios; J parameter; decay

326 constants...) and reference sources are available in a complementary data repository.

\subsection{U-Th-Pb LA-ICP-MS and ${ }^{40}$ Ar- ${ }^{39}$ Ar results}

\subsubsection{Sample ES7 - Laouzas granite}

330 Zircon and monazite grains were both recovered from this sample. Most of the zircon grains were pink in colour, euhedral, with very variable shapes from elongated to oval.

332 Cathodoluminescence imaging revealed a rather heterogeneous population with anything

333 from homogeneous low luminescent to heterogeneous (core + rim) grains (Fig. 3A). Thirty-

334 seven analyses out of twenty-six zircon grains were made (Table 1). The heterogeneity of the

335 grains is confirmed in a Tera-Wasserburg diagram (Fig. 4A) where data points plot in a

336 concordant to very discordant position with apparent ${ }^{207} \mathrm{~Pb} /{ }^{206} \mathrm{~Pb}$ ages ranging from $1010 \mathrm{Ma}$

337 down to 370 Ma. Because of this heterogeneity, which is probably caused by a complex

338 mixing of heterogeneous inheritance, plus variable degree of common $\mathrm{Pb}$ content and $\mathrm{Pb}$ loss,

339 it is not possible to calculate any relevant ages. We therefore favoured plotting the data in a

340 relative probability plot diagram (Fig. 4E) where only the ${ }^{207} \mathrm{~Pb} /{ }^{206} \mathrm{~Pb}$ apparent ages for the

341 more than $90 \%$ concordant points were considered. One main peak can be defined at ca. 500

342 Ma, with minor peaks around 700 and 800 Ma.

343 Two types of monazite grains were found in this sample. Type 1 monazite comprises

344 euhedral dark brown grains with sharp concentric zoning (Fig. 5) and type 2 monazite

345 comprises euhedral to subhedral yellowish to orange grains characterised by complex patchy

346 zoning (Fig. 6), as revealed by backscattered electron (BSE) imaging. Elemental imaging

347 carried out using the NanoSIMS ion probe reveals that the concentric zoning for type 1

348 monazite (Fig. 5) is visible with all the elements imaged (Y, La, Ce, Sm, U, Th and Pb) with

349 cores that are LREE-rich and poor in $\mathrm{Y}, \mathrm{U}, \mathrm{Th}$ and $\mathrm{Pb}$. More importantly, the distributions of 
$\mathrm{U}$ and $\mathrm{Th}$ in this monazite type perfectly match each other. For type 2 monazite (Fig. 6 ), the 351 complex zoning noticed in BSE images is well mimicked by the distribution of Y, REE, U 352 and ${ }^{206} \mathrm{~Pb}$ while the distribution of Th and ${ }^{208} \mathrm{~Pb}$ is less disturbed. analyses (11 grains) were performed directly in a thin section. In total, 50 analyses were carried out (Table 2). Plotted in a ${ }^{206} \mathrm{~Pb} /{ }^{238} \mathrm{U}$ versus ${ }^{208} \mathrm{~Pb} /{ }^{232} \mathrm{Th}$ concordia diagram (Fig. 4B), the two types plot in two distinct groups. For the monazite grains dated in context in the thin sections, there is no evident correlation between the mineral hosting the monazite grains and their apparent ages. Therefore, the location of type 1 and type 2 monazite is not related to any specific host mineral. Type 1 monazite $(\mathrm{N}=26$; grains with sharp concentric zoning) plots in a concordant to slightly discordant position. A cluster of 14 concordant analyses (Fig. 4B) yields a concordia age (Ludwig 1998) of $318.0 \pm 1.4 \mathrm{Ma}(\mathrm{MSWD}=0.87)$. This concordia age is equivalent within error to the average ${ }^{206} \mathrm{~Pb} /{ }^{238} \mathrm{U}$ date of $318.8 \pm 1.5 \mathrm{Ma}(\mathrm{N}=26$; MSWD $=$ 0.95 ) obtained for the 26 analyses defining this first group. Interestingly, the ${ }^{208} \mathrm{~Pb} /{ }^{232} \mathrm{Th}$ apparent ages for this group display a bimodal distribution (see Fig. 4G), with one peak at $331.5 \pm 2 \mathrm{Ma}$ and a second one at $319.1 \pm 2.0 \mathrm{Ma}$.

Data obtained on type 2 monazite (grains with complex patchy zoning; $\mathrm{N}=20$ ) exhibits a slight reverse discordance (Fig. 4B). The mean ${ }^{206} \mathrm{~Pb} /{ }^{238} \mathrm{U}$ date obtained for these twenty analyses is consistent with a value of $293.5 \pm 1.7 \mathrm{Ma}(\mathrm{MSWD}=0.78)$ while the ${ }^{208} \mathrm{~Pb} /{ }^{232} \mathrm{Th}$ apparent dates yield average dates of $285.2 \pm 2.2 \mathrm{Ma}(\mathrm{MSWD}=0.66 ; \mathrm{N}=8)$ for the grains analysed in the epoxy puck and of $296.5 \pm 2.8 \mathrm{Ma}(\mathrm{MSWD}=0.42 ; \mathrm{N}=7)$ for the grains dated in the thin section (Fig. 4G).

Muscovite single grain from sample ES7 yielded a flat ${ }^{40} \mathrm{Ar}-{ }^{39} \mathrm{Ar}$ age spectrum (Fig. 4H) over most of ${ }^{39} \mathrm{Ar}_{\mathrm{K}}$ degassing (ca. 95\%), corresponding to a calculated plateau age of $298.2 \pm 0.8 \mathrm{Ma}(2 \sigma$ level$)$. 
377 Both monazite and zircon grains were extracted from this sample. Two types of zircon grains 378 were found. The first type is characterized by elongate pinkish grains (Fig. 3B), while the 379 second type is constituted by squat prismatic grains (Fig. 3C). Both types display complex 380 zoning with core and rims apparent for most (Fig. 3B and C). Thirty-two analyses were 381 performed on twenty-eight grains (Table 1). Plotted in a Tera-Wasserburg diagram (Fig. 4C), 382 they plot in a concordant to discordant position, with apparent ${ }^{207} \mathrm{~Pb} /{ }^{206} \mathrm{~Pb}$ ages ranging from ca. 2650 down to $300 \mathrm{Ma}$. Once again, it is difficult to get any valuable geochronological constraint with this set of data. Plotted in a relative probability plot (Fig. 4E), two main peaks arise at ca. $610 \mathrm{Ma}$ and $875 \mathrm{Ma}$, with minor peaks at 690, 1000, 1310 and $2450 \mathrm{Ma}$. From a morphological point of view, all monazite crystals were yellow and euhedral to subhedral. Forty-six analyses were performed (38 on separated grains and 8 directly in context in thin sections). Plotted in a ${ }^{206} \mathrm{~Pb} /{ }^{238} \mathrm{U}$ versus ${ }^{208} \mathrm{~Pb} /{ }^{232} \mathrm{Th}$ concordia diagram (Fig. 4D), they all plot in a concordant to slightly discordant position. A first group of 14 analyses defines a concordia ages of $318.5 \pm 0.7 \mathrm{Ma}(\mathrm{MSWD}=1.3$; Fig. 4D). A second cluster of 15 analyses yields a concordia age of $298.8 \pm 1.3 \mathrm{Ma}(\mathrm{MSWD}=0.68$; Fig. 4D). The remaining 17 analyses plot in a slightly reverse discordant position either between the two previous calculated concordia dates or are apparently younger than 299 Ma (Fig. 4D). The two analyses performed in monazite grains hosted by quartz yielded dates close to $290 \mathrm{Ma}$ while the monazite grains hosted by biotite plot in a scattered position. When looking at the BSE imaging, the first group (ca. 318.5 Ma) is characterized by 397 fairly homogeneous monazite grains (Fig. 7), while monazite in the second group (ca. 299 398 Ma) is characterized by more patchy zoning (Fig. 8). The NanoSIMS imaging of the first 399 group confirms the rather homogeneous distribution of the imaged elements with the 
exception of $\mathrm{U}$ and $206 \mathrm{~Pb}$ that appear to be poorer in the core of the grain (Fig. 7). For the second group, the elemental distributions are not as simple. The REE distribution seems to be homogeneous throughout the grain whereas the $\mathrm{Y}, \mathrm{U}, \mathrm{Th}$ and $\mathrm{Pb}$ distributions are patchier (Fig. 8).

Similar to monazite in ES7, monazite data in ES8 are characterized by evident differences between the $206 \mathrm{~Pb} / 238 \mathrm{U}$ and the $208 \mathrm{~Pb} / 232 \mathrm{Th}$ dates (Fig. $4 \mathrm{~F}$ and $\mathrm{G}$ ). The $208 \mathrm{~Pb} / 232 \mathrm{Th}$ dates fall into 3 distinct populations (Fig. $4 \mathrm{G})$ at $319.8 \pm 1.8 \mathrm{Ma}(\mathrm{MSWD}=1.3$; $\mathrm{N}=15), 298.2 \pm 1.5 \mathrm{Ma}(\mathrm{MSWD}=0.89 ; \mathrm{N}=19)$ and $284.7 \pm 2.1 \mathrm{Ma}(\mathrm{MSWD}=0.98 ; \mathrm{N}=$ 8), respectively. $206 \mathrm{~Pb} / 238 \mathrm{U}$ dates define two different peaks at 316.2 $\pm 1.9 \mathrm{Ma}(\mathrm{MSWD}=$ $0.68 ; \mathrm{N}=15)$ and 296.1 $\pm 1.3 \mathrm{Ma}(\mathrm{MSWD}=2.8 ; \mathrm{N}=26)$, respectively (Fig. 4F).

Muscovite single grain from sample ES8 yielded a flat 40Ar-39Ar age spectrum (Fig. 4H) over most of 39ArK degassing (ca. 98\%) that correspond to a calculated plateau age of $298 \pm 1 \mathrm{Ma}(2 \sigma$ level$)$. This age is similar to the ES7 plateau age.

\section{Geological significance of the geochronological data}

\subsection{Zircon dating}

Zircon data from both the Laouzas granite and the La Salvetat migmatite show a considerable spread (Fig. 4E) and cannot be used to either date the emplacement of the granite or the age of migmatization. They rather demonstrate the existence of a complex polygenic history in the region, with dates ranging from the late Archean to the Ordovician. They are consistent with the data published by Faure et al. (2010), although more date populations were found in our study. In the La Salvetat migmatite, the youngest point (grain 1.1d) that plots close to the concordia gives a ${ }^{207} \mathrm{~Pb} /{ }^{206} \mathrm{~Pb}$ date of $337 \pm 27 \mathrm{Ma}$ (1 sigma). This grain might have grown 
424 during the migmatization, but because of its large error, it does not help to constrain this event 425 precisely.

\subsection{Monazite dating}

\subsubsection{The Laouzas granite}

In the ${ }^{206} \mathrm{~Pb} /{ }^{238} \mathrm{U}$ versus ${ }^{208} \mathrm{~Pb} /{ }^{232} \mathrm{Th}$ concordia diagram (Fig. 4B), the monazite grains

429 from the Laouzas granite plot in two clusters although the geochronological information

430 brought, for each cluster, by the monazite grains ${ }^{206} \mathrm{~Pb} /{ }^{238} \mathrm{U}$ and ${ }^{208} \mathrm{~Pb} /{ }^{232} \mathrm{Th}$ respective dates is

431 different. Indeed, within each cluster, the ${ }^{206} \mathrm{~Pb} /{ }^{238} \mathrm{U}$ dates are comparable, while they are 432 more scattered in the case of the ${ }^{208} \mathrm{~Pb} /{ }^{232} \mathrm{Th}$ ones.

To first order, four dates can be defined for the Laouzas granite. The oldest date at ca.

434330 Ma can be calculated using the older apparent ${ }^{208} \mathrm{~Pb} /{ }^{232} \mathrm{Th}$ dates (Fig. 4G). The second one around $319 \mathrm{Ma}$ is given by a concordia age of $318.0 \pm 1.4 \mathrm{Ma}$ (Fig. 4B), the mean ${ }^{206} \mathrm{~Pb} /{ }^{238} \mathrm{U}$ date of $318.8 \pm 1.5 \mathrm{Ma}$ obtained for all the analyses from the older cluster (Fig. 4B) and from one of the peaks defined by the ${ }^{208} \mathrm{~Pb} /{ }^{232} \mathrm{Th}$ dates at $319.1 \pm 2.0 \mathrm{Ma}$ (Fig. 4G). The third date of around 298-292 Ma is defined by one peak in the ${ }^{208} \mathrm{~Pb} /{ }^{232} \mathrm{Th}$ dates distribution at $298.2 \pm 1.5 \mathrm{Ma}$ (Fig. 4G) and the mean ${ }^{206} \mathrm{~Pb} /{ }^{238} \mathrm{U}$ date of $293.5 \pm 1.7$ Ma calculated for the

440 second group (Fig. 4B). This third date is in a good agreement with the ${ }^{40} \mathrm{Ar}-{ }^{39} \mathrm{Ar}$ age of 298.2 $441 \pm 0.8 \mathrm{Ma}(2 \sigma$ level$)$ obtained on muscovite from the same sample (Fig. 4H). Finally, the 442 youngest date around $285 \mathrm{Ma}$ is defined by the youngest ${ }^{208} \mathrm{~Pb} /{ }^{232} \mathrm{Th}$ dates (Fig. 4G). It seems evident that the dates of ca. $319 \mathrm{Ma}$ and ca. $298 \mathrm{Ma}$ are representative of

444 specific events as they are common to both chronometers $(\mathrm{U} / \mathrm{Pb}$ and $\mathrm{Th} / \mathrm{Pb})$ and because the 445 second one is also defined by ${ }^{40} \mathrm{Ar}-{ }^{39} \mathrm{Ar}$ dating. Therefore, two scenarios can be suggested. 446 Either the date of ca. 319 Ma yields the emplacement age of the Laouzas granite and the date 447 of ca. $298 \mathrm{Ma}$ is related to a post emplacement event, or the granite was emplaced ca. $298 \mathrm{Ma}$ 448 ago, in which case the date of ca. 319 Ma should be regarded as "inherited". Three 
observations are helpful to discriminate between these two scenarios. (i) The backscattered imaging shows that the ca. 319 Ma monazite population (Type 1) is characterized by a rather simple concentric zoning, whereas the ca. 298 Ma old population (Type 2) systematically displays a complex patchy zoning. Concentric zoning is consistent with a magmatic origin, whereas patchy zoning suggests the involvement of a post-crystallization perturbing event, such as fluid-related dissolution/recrystallization (Williams et al. 2011; Tartèse et al. 2011; Didier et al. 2013). (ii) As noticed on the NanoSIMS imaging (Fig. 5 and 6), the elemental distributions perfectly match for the Type 1 monazite while they differ for Type 2. (iii) Finally, petrographic observations suggest an overprint of the primary magmatic assemblage associated with a later circulation of hydrothermal fluids. In the light of these observations, we propose that the Laouzas granite was emplaced ca. 319 Ma ago and was affected by a post-emplacement, fluid-related event, ca. $298 \mathrm{Ma}$ ago. In this case, the ${ }^{40} \mathrm{Ar}-{ }^{39} \mathrm{Ar}$ age at 298.2 \pm 0.8 Ma yielded by muscovite from the same sample would also characterize this late hydrothermal event, since it has been shown that the K-Ar geochronometer in muscovite can be highly sensitive to fluid circulations in granites in a similar context (Questembert

464 leucogranite, Armorican massif, France) by Tartèse et al. (2011). phenomenon has also been noticed by Tartèse et al. (2012) for monazite grains from a mylonitized granite from the South Armorican Shear Zone, in which the ${ }^{208} \mathrm{~Pb} /{ }^{232} \mathrm{Th}$ dates

468 (defining an average date of $313 \pm 3 \mathrm{Ma}$ ) were systematically older than the U-Pb dates 469 (defining an average date of $299 \pm 4 \mathrm{Ma}$ ). A recent study by Didier et al. (2013) has 470 demonstrated that F-rich fluids can be responsible for the disturbance of the $\mathrm{Th} / \mathrm{Pb}$ ratios in 471 monazite and the incorporation of excess $\mathrm{Pb}$, leading to a large spread of the ${ }^{208} \mathrm{~Pb} /{ }^{232} \mathrm{Th}$ 472 dates. Disturbed ${ }^{208} \mathrm{~Pb} /{ }^{232} \mathrm{Th}$ and ${ }^{206} \mathrm{~Pb} /{ }^{238} \mathrm{U}$ data were also obtained by Poitrasson et al. (2000) 473 and were attributed to variable inputs and/or depletions in $\mathrm{U}$, $\mathrm{Th}$ and $\mathrm{Pb}$ in the monazite 
crystals during hydrothermal alteration. As detailed earlier, the Laouzas anatectic granite bears petrographic evidence of hydrothermal fluid circulation. We therefore believe that this date of ca. $330 \mathrm{Ma}$ is meaningless and is attributed to fluid perturbation of some of the monazite grains leading to a fractionation of their $\mathrm{Th} / \mathrm{Pb}$ ratios (cf. Didier et al. 2013). The other date at ca. $285 \mathrm{Ma}$ is also obtained with only the ${ }^{208} \mathrm{~Pb} /{ }^{232} \mathrm{Th}$ dates. Once again, either this date is related to a fluid-induced perturbation of the monazite $\mathrm{Th}-\mathrm{Pb}$ isotope system, and is, therefore, meaningless, or it reflects the age of a yet unknown event in the region.

\subsubsection{La Salvetat migmatite}

Monazite from the La Salvetat migmatite also yields different ${ }^{208} \mathrm{~Pb} /{ }^{232} \mathrm{Th}$ and ${ }^{206} \mathrm{~Pb} /{ }^{238} \mathrm{U}$ dates but here again two main dates can be proposed. A first one at ca. $319 \mathrm{Ma}$ is given by a concordia age of $318.5 \pm 0.7 \mathrm{Ma}($ Fig. $4 \mathrm{D})$, a mean ${ }^{208} \mathrm{~Pb} /{ }^{232} \mathrm{Th}$ date of $319.8 \pm 1.8$ $\mathrm{Ma}$ (Fig. 4G) and a mean ${ }^{206} \mathrm{~Pb} /{ }^{238} \mathrm{U}$ date of $316.2 \pm 1.9 \mathrm{Ma}$ (Fig. 4F). The second one, around $298 \mathrm{Ma}$, is given by a concordia age of $298.8 \pm 1.3 \mathrm{Ma}\left(\right.$ Fig. 4D), a mean ${ }^{208} \mathrm{~Pb} /{ }^{232} \mathrm{Th}$ date of $298.2 \pm 1.5 \mathrm{Ma}$ (Fig. 4G), a mean ${ }^{206} \mathrm{~Pb} /{ }^{238} \mathrm{U}$ date of $296.1 \pm 1.3 \mathrm{Ma}$ (Fig. 4F) and a muscovite ${ }^{40} \mathrm{Ar}-{ }^{39}$ Ar plateau age of $298 \pm 1 \mathrm{Ma}($ Fig. $4 \mathrm{H})$.

Lastly, the youngest ${ }^{208} \mathrm{~Pb} /{ }^{232} \mathrm{Th}$ dates define a mean date of $284.7 \pm 2.1 \mathrm{Ma}$. Monazite is known to be very resistant to diffusional reequilibration (e.g. Seydoux-Guillaume et al. 2002; Gardés et al. 2007), preserving the age of their crystallisation. On the other hand, they recrystallize readily by dissolution/precipitation processes, when fluids or magmas are involved (Williams et al. 2011; Tartèse et al. 2011; Didier et al. 2013). As a general rule, two major "pulses" of monazite growth are predicted in metapelitic rocks: subsolidus growth in the upper amphibolite facies and growth during the cooling of leucosomes (rather than partial melting) following migmatization (e.g. Foster et al. 2000; Rubatto et al. 2001; Kelsey et al. 2008; Spear and Pyle 2010). Furthermore, it is now well established that monazite may 
(re)crystallise due to fluid-rock interactions relatively late in the metamorphic history (e.g. Bosse et al. 2009; Tartèse et al. 2011, 2012; Didier et al. 2013).

Consequently, the three dates of ca. 319, ca. 298 and ca. 284 Ma obtained for the monazite grains from the La Salvetat migmatite, may represent the ages of: (1) crystallisation during the prograde metamorphism in the upper amphibolite facies conditions; (2) crystallisation of the leucosomes following partial melting and (3) recrystallisation due to late fluid circulations, respectively. On the other hand, the close spatial and inferred genetic association of the migmatites with the Laouzas granite suggests that monazite grains of the same age should be found in both rock types. The crystallisation of the Laouzas granite is inferred to have taken place at ca. $319 \mathrm{Ma}$ (see earlier), suggesting that the date of $319 \mathrm{Ma}$ in the La Salvetat migmatite should be interpreted as the age of the crystallisation of the leucosomes, rather than that of the prograde amphibolite-facies metamorphism. The second date of ca. $298 \mathrm{Ma}$ found in the migmatite is identical within error to the date of ca. $298 \mathrm{Ma}$ found in the Laouzas granite, but also to the emplacement age of $294 \pm 3 \mathrm{Ma}(\mathrm{U}-\mathrm{Pb}$ on zircon) obtained for the syntectonic Montalet leucogranite (Poilvet et al. 2011), situated about $20 \mathrm{~km}$ to the NW (Fig. 1). It is conceivable that a second phase of partial melting of the La Salvetat migmatite was the source of this leucogranite but the poor outcrop conditions do not allow to validate such hypothesis. Alternatively and more probably, partial melting of other deeper formations formed the Montalet magmas, which percolated with associated fluids through the crust, resulting in the recrystallization of some monazite grains in the migmatite-granite dome, as suggested by the late fluid circulations inferred from the petrographic observations of the La Salvetat migmatite. A detailed study of the geochemical affinities between the migmatites and the various granites would be necessary to answer this question. Finally, the $284 \mathrm{Ma}$ date, identical within uncertainty to the date of ca. $285 \mathrm{Ma}$ obtained in the Laouzas granite is, as argued above, either an artefact due to fluid-enhanced 
modification of some of the monazite crystals, or, an evidence of a younger, although unidentified, event in the region. Similar Permian ages are known elsewhere in the European Variscan belt. Mougeot et al. (1997) reported an U-Pb apatite age ca. 289 Ma for the Velay granite. Cathelineau et al. (1990) obtained Permian ages on vein-type deposits from the Mortagne district in the South Armorican Massif and the French Massif Central, with a major stage of uranium mobilization between 290 and 260 Ma. In the Erzgebirge (Germany), the emplacement of vein-type deposits is also Permian in age and postdates the emplacement of the youngest Variscan granites by no less than 20-25 Ma (e.g. Velichkin and Vlasov, 2011 and references therein). More recently, Boutin et al. (2015) reported some Permian U-Pb ages obtained on titanite associated with chlorite-talc mineralization in the Pyrenees. This nonexhaustive list demonstrates that this date of ca. $285 \mathrm{Ma}$ is not unique at the scale of the Variscan belt as numerous ore deposits linked to fluid circulations are contemporaneous, and could, therefore, be considered as meaningful for the Montagne Noire. Finally, the remaining data that plot in a scattered position (Fig. 4D) could be attributed to an incomplete resetting of their U-Th-Pb system during the subsequent fluid circulation events.

\subsection{Partial melting and regional correlations}

In summary, the Laouzas granite and the La Salvetat migmatite are spatially close and petrographically similar. The Laouzas granite is therefore interpreted as a product of the partial melting recorded in the La Salvetat migmatite. Monazite grains from both rocks recorded a date of ca. $319 \mathrm{Ma}$, which is interpreted as the emplacement age of the Laouzas granite, and hence also that of a first stage of migmatization (or rather the crystallisation of the leucosomes resulting from this partial melting). The date of ca. $298 \mathrm{Ma}$ is tentatively attributed either to a second stage of migmatization, or more probably to a pervasive percolation of magmas and associated fluids coming from a deeper source and resulting in the syntectonic crystallisation of the more superficial Montalet leucogranite. 
It is interesting to draw a parallel with the scenario described for the Velay gneiss

550 dome, located some $150 \mathrm{~km}$ ENE of the Montagne Noire. In this area, Montel et al. (1992)

551 described two successive stages of migmatization that have been dated at $314 \pm 5 \mathrm{Ma}$ and 301

$552 \pm 5 \mathrm{Ma}(\mathrm{U}-\mathrm{Pb}$ ID-TIMS on monazite, Mougeot et al., 1997). Barbey et al. (2015) suggest

553 three melting events, estimated to have occurred at 325-315 Ma, ca. $305 \mathrm{Ma}$, and 305-

$554295 \mathrm{Ma}$. In addition, Roger et al. (2015) bracketed the high temperature deformation and

555 metamorphism both in the Gorges d'Héric and the Vialais granite between 310-300 Ma.

556

\section{Tectonic implications for the formation of the Montagne Noire dome}

Two major hypotheses are proposed at present to explain the origin of the Montagne Noire

dome. Both agree on the presence of compressional and extensional features, but disagree on

560 their timing and their relative importance. The first hypothesis considers that the domal

561 structure developed as a regional anticline during the collisional stage of the Variscan

562 orogeny (e.g. Arthaud et al. 1966; Burg and Matte 1978, Charles et al. 2009) and interpret the

563 extensional features as second-order and late with respect to the formation of the dome. For

564 the second hypothesis, dome-like exhumation of the lower continental crust beneath a major

565 crustal-scale extensional detachment is at the origin of the Montagne Noire dome (Van Den

566 Driessche and Brun 1989; Echtler and Malavieille 1990; Van Den Driessche and Brun 1992).

567 Beyond the structural record, this second hypothesis is supported and constrained in time by

568 the syntectonic emplacement of a leucogranite at ca. $295 \mathrm{Ma}$ (Poilvet et al. 2011) and by

569 monazite and mica ages of ca. $295 \mathrm{Ma}$ in sheared metasediments and orthogneisses (Maluski

570 et al. 1991; Pitra et al. 2012) along the detachment that is contemporaneous with and controls

571 the development of the Stephanian to Permian Graissessac and Lodève basins (Fig. 1; Van

572 Den Driessche and Brun 1989; Bruguier et al. 2003). In contrast, the advocates of the

573 compressional origin of the dome either associate the extensional structures exclusively with 
574 the compressional phase (Brunel and Lansigu 1997), or relegate it to a secondary role in the

575 brittle domain (Matte et al. 1998; Charles et al. 2009). The principal argument was the age of 576 the late- to post-kinematic Vialais granite, supposedly dated at $327 \pm 5 \mathrm{Ma}$ (TIMS on zircon 577 and monazite fractions; Matte et al. 1998), emplaced in the central-eastern part of the dome 578 (Fig. 1), and the ca. 330 Ma dates obtained by electron probe micro-analysis (EPMA) 579 monazite dating from migmatites and anatectic granites summarised in Charles et al. (2009) 580 and Faure et al. (2010). In the "compressional" interpretation, migmatization and magmatism predate extension. In the "extensional" interpretation, which requires thermal relaxation and related rheological softening in order for the crust to collapse, migmatization is also contemporaneous with the onset of extension, especially because extension can enhance partial melting by adiabatic decompression (e.g. Hollister 1993; Holtz and Johannes 1994; Holtz et al. 2001; Thompson 2001). Clearly, the clue is to be sought in the absolute timing of regional migmatization and related granite emplacement.

First, the Vialais granite and an associated post-kinematic leucogranite have been 589 recently re-dated at $303 \pm 4 \mathrm{Ma}$ and $298 \pm 2 \mathrm{Ma}$, respectively (U-Pb monazite ICP-MS ages, 590 Roger et al. 2015). Second, our data support a genetic link between the migmatites and 591 granites in the "axial zone" of the Montagne Noire gneiss dome. Three age groups were 592 identified from the monazite $\mathrm{U}-\mathrm{Th} / \mathrm{Pb}$ data. A first event, at ca. $319 \mathrm{Ma}$, is recorded in both 593 the La Salvetat migmatite and the Laouzas granite, and is interpreted as the end of a first stage 594 of migmatization and as the emplacement age of the Laouzas granite, respectively. A second 595 event, at ca. $298 \mathrm{Ma}$, is recorded in the migmatite and in the Laouzas granite, and could be 596 interpreted as a fluid-induced event, probably related to a second melting event identified 597 through the emplacement of the Montalet and Vialais leucogranites. The third event, dated 598 around $285 \mathrm{Ma}$, although not clear, could be linked to Permian fluid circulations. The 
presence of two stages of partial melting at ca. $320 \mathrm{Ma}$ and ca. $300 \mathrm{Ma}$ confirms (i) the

600 interpretation of the Late Carboniferous-Early Permian evolution of the Variscan belt

601 dominated by the extensional collapse, which predicts migmatization both preceding and

602 contemporaneous of the onset of extension, and (ii) the interpretation of the Montagne Noire

603 dome as an extensional gneiss dome.

604

605

\section{EPMA versus LA-ICP-MS dating}

606 In recent years, some studies comparing monazite ages obtained by the LA-ICP-MS and

607 EPMA techniques encountered discrepancies between both sets of ages (Paquette and Tiepolo 608 2007; Poilvet et al. 2011 and references therein). Other studies also pointed out that EPMA 609 dating should be acquired with caution as, for example, incorrect determination of 610 background intensities could result in artificially older ages (Jercinovic and Williams 2005; 611 Spear et al. 2009).

612 This study offers, therefore, the opportunity to compare the results obtained through 613 EPMA chemical dating and those obtained by LA-ICP-MS. Indeed, two aspects differ 614 between our data and those of Faure et al. (2010) - (i) a minimum of two generations of 615 monazite are distinguished in our data set whereas only one was identified in Faure et al 616 (2010), and (ii) there is a significant difference in the absolute ages obtained by both 617 approaches. Although Faure et al. (2010) identified "three groups of composition according to the $619 \mathrm{Th} / \mathrm{U}$ ratio" (p. 660) for monazite grains from the La Salvetat migmatite, they interpreted 620 them in terms of only one chemical date of $327 \pm 7 \mathrm{Ma}$, reflecting the crystallization age of 621 these monazite grains. This age is barely within error of the oldest age of $319.8 \pm 1.8 \mathrm{Ma}$ 622 found in this study, although the latter is more precise. However, one more age at $298 \mathrm{Ma}$ was 623 obtained by LA-ICP-MS (with another possible event at ca. $285 \mathrm{Ma}$ ). In the case of the 
624 monazite from the Laouzas granite, EPMA dating yielded only one date at $336 \pm 6 \mathrm{Ma}$,

625 whereas at least two (potentially four) were obtained by LA-ICP-MS. In this case, Faure et al.

626 (2010) describe their monazite as patchy zoned, a feature encountered only in our younger

627 monazite population dated at ca. $298 \mathrm{Ma}$. The fact that they did not find two age populations

628 in their data set could be explained if they did not encounter the concentrically zoned

629 monazite in their samples.

630 These differences could also be linked to the statistical treatment applied to EPMA

631 dating. Indeed, each individual analysis bares fairly high error, but once they are all combined

632 to calculate a total $\mathrm{U}-\mathrm{Th}-\mathrm{Pb}$ date, the resulting error becomes relatively small $(\leq 2 \%)$. One

633 could therefore argue that this statistic treatment is not able to resolve different populations

634 that are relatively close in age.

635 In order to test this hypothesis, we took the $\mathrm{U}$, Th and $\mathrm{Pb}$ contents calculated for three

636 of our samples (ES7 and ES8, this study Table 2; ES5 of Poilvet et al. 2011), and ran them

637 into the EPMA dating add-in developed by Pommier et al. (2002) following the data

638 treatment described in Cocherie et al. (1998) and Cocherie and Albarède (2001). In order to

639 test the viability of our approach, we first took the data from the Montalet granite in Poilvet et

640 al. (2011). The monazite grains in this sample yielded a single concordia age of $294 \pm 1 \mathrm{Ma}$,

641 identical to the concordia age of $294 \pm 3 \mathrm{Ma}$ obtained on zircon. Plotted in a $\mathrm{Th} / \mathrm{Pb}$ versus

$642 \mathrm{U} / \mathrm{Pb}$ diagram (Fig. 9A), they define a similar U-Th-Pb age of $295 \pm 10 \mathrm{Ma}$. This

643 demonstrates that when dating a simple (i.e. single age) population of monazite, the results

644 obtained by both the LA-ICP-MS and EPMA dating techniques are comparable. We then

645 tested this approach with two other samples from this study, which gave several age

646 populations. For sample $\mathrm{ES7}$, the resulting $\mathrm{Th} / \mathrm{Pb}$ versus $\mathrm{U} / \mathrm{Pb}$ isochron diagram (Fig. 9B)

647 allows to calculate a single U-Th-Pb date of $297 \pm 15 \mathrm{Ma}(\mathrm{MSWD}=0.28)$ at the centroid of

648 the population. In this diagram, the regression line lies fairly close to the theoretical isochron, 
therefore this age of ca. 297 Ma would have been considered as reliable and, therefore,

650 unique. Yet, we know that in fact at least two ages can be calculated using the LA-ICP-MS

651 data (ca. 319 Ma and ca. 298 Ma respectively). Although these two ages are $\sim 20$ Ma apart,

652 the $\mathrm{Th} / \mathrm{Pb}$ versus $\mathrm{U} / \mathrm{Pb}$ isochron diagram is not able to distinguish them. If we do the same

653 operation with monazite data from sample ES8, we also end up with a U-Th-Pb chemical age

654 of $291 \pm 8 \mathrm{Ma}(\mathrm{MSWD}=0.18)$ at the centroid of the population (Fig. 9C) although three ages

655 can be calculated in a conventional concordia diagram (ca. $319 \mathrm{Ma}, 298 \mathrm{Ma}$ and, maybe, 284

$656 \mathrm{Ma})$. In this case we reached the limits of the technique as the theoretical isochron fits just

657 within the limits of the error envelope. This does not explain however why the EPMA ages

658 found by Faure et al. (2010) are significantly older than the ages found by LA-ICP-MS.

659 It is interesting to note that, with the same data set, but using the procedure described

660 in Montel et al. (1996) where, for each individual age, the 95\% confidence interval is

661 estimated by a Monte Carlo procedure assuming $\mathrm{U}$, Th and $\mathrm{Pb}$ content to obey a Gaussian

662 distribution, we end up with completely different results, as the age distributions for sample

663 ES7 yield three different date peaks at ca. $318 \mathrm{Ma}, 302 \mathrm{Ma}$ and $270 \mathrm{Ma}$ (Fig. 10), which is in

664 a good agreement with the ages found in this study.

665

666 7. Conclusion

667 The presence of two stages of partial melting, at ca. $320 \mathrm{Ma}$ and ca. $300 \mathrm{Ma}$, confirms (i) the

668 interpretation of the Late Carboniferous-Early Permian evolution of the Variscan belt

669 dominated by extensional collapse, which predicts migmatization both preceding, and

670 contemporaneous with, the onset of extension, and (ii) the interpretation of the Montagne

671 Noire dome as an extensional gneiss dome.

672 We also demonstrate that EPMA dating of monazite in this type of complex poly-

673 phased environment should be used with extreme caution. Indeed, as illustrated here, the $\mathrm{Pb} / \mathrm{U}$ 
674 and $\mathrm{Th} / \mathrm{U}$ isochron statistical data treatment (Pommier et al. 2002) can sometimes fail to

675 resolve different age populations and can, therefore, produce erroneous results.

676

677

678 Acknowledgments

679 Xavier Le Coz is acknowledged for making promptly the thin sections required for our study,

680 Yann Lepagnot for the efficient rock crushing. Thomas Delhaye for help with NanoSIMS

681 analysis. Jean-Marc Montel and an anonymous reviewer are thanked for their constructive

682 remarks of a previous version of this manuscript. The reviews of P. Rey and E. Oliot are

683 acknowledged.

684

685

686

687

688

689

\section{References}

Alabouvette B, Demange M (1993) Notice explicative, Carte géol. France (1/50 000), feuille

690 Saint-Pons (1013). Orléans, BRGM, 123 pp

691 Arthaud F (1970) Etude tectonique comparée de deux domaines hercyniens : les nappes de la

692 Montagne Noire (France) et l'anticlinorium de l'Igliesente (Sardaigne), Thesis, Universiy of

693 Montpellier, Publications USTELA Géol. Struct., 175 pp

694 Arthaud F, Mattauer M, Proust F (1966) La structure et la microtectonique des nappes

695 hercyniennes de la Montagne Noire. In: Etages tectoniques : Colloque de Neuchâtel, 18-19

696 avril 1966, Université de Neuchâtel, 231-243.

697 Arthaud F, Matte P (1977) Late Paleozoic strike slip faulting in southern Europe and northern

698 Africa: Result of a right-lateral shear zone between the Appalachians and the Urals.

699 Geological Society of America Bulletin 88:1305-1320.

700 Barbey P, Villaros A, Marignac C, Montel J-M (2015) Multiphase melting, magma

701 emplacement and P-T-time path in late-collisional context: the Velay example (Massif

702 Central, France). Bull. Soc. géol. Fr. 186(2-3):93-116 
Becq-Giraudon JF, Van Den Driessche J (1993) Continuité de la sédimentation entre le Stéphanien et l'Autunien dans le bassin de Graissessac-Lodève (sud du Massif Central) : implications tectoniques. Comptes Rendus de l'Académie des Sciences série 2, 317:939-945. Benard F, Moutou P, Pichavant M (1985) Phase Relations of Tourmaline Leucogranites and the Significance of Tourmaline in Silicic Magmas. Journal of Geology 93:271-291.

Blès J-L, Bonijoly C, Castaing C, Gros Y (1989) Sucessive post-Varican stress fields in the French Massif Central and its borders (Western European plate): comparison with geodynamica data. Tectonophysics 169: 79-111.

Bogdanoff S, Donnot F, Ellenberger F (1984) Note explicative, Carte géol. France (1/50 000), feuille Bédarieux (988),. Orléans, BRGM, 105 pp

Bosse V, Boulvais P, Gautier P, Tiepolo M, Ruffet G, Devidal J-L, Cherneva Z, Gerdjikov I, Paquette J-L (2009) Fluid-induced disturbance of the monazite Th-Pb chronometer: In situ dating and element mapping in pegmatites from the Rhodope (Greece, Bulgaria). Chemical Geology 261:286-302.

Boutin A, de Saint Blanquat M, Poujol M, Boulvais P, de Parseval P, Rouleau C, Robert JF (2015). Succession of Permian and Mesozoic metasomatic events in the eastern Pyrenees with emphasis on the Trimouns talc-chlorite deposit. International Journal of Earth Sciences, doi:10.1007/s00531-015-1223-x.

Brun J-P, Van Den Driessche J (1994) Extensional gneiss domes and detachment fault systems: structures and kinematics. Bulletin de la Société Géologique de France 165:519-530.

Bruguier O, Becq-Giraudon JF, Champenois M, Deloule E, Ludden J, Mangin D (2003) Application of in situ zircon geochronology and accessory phase chemistry to constraining basin development during post-collisional extension: a case study from the French Massif Central. Chemical Geology 201:319-336.

Brunel M, Lansigu C (1997) Déformation et cinématique de mise en place du dôme de la zone axiale de la Montagne Noire: signification des nodules à quartz-sillimanite (Massif central français) [Deformation and kinematics of emplacement of the axial dome of the Montagne Noire: implications of quartz-sillimanite nodule attitudes (French Massif Central)]. Comptes Rendus de l'Académie des Sciences Paris - Series IIA - Earth and Planetary Sciences 325:517-523. 
733 Burg J-P, Matte PJ (1978) A Cross Section through the French Massif Central and the Scope 734 of its Variscan Geodynamic Evolution. Zeitschrift der Deutschen Geologischen Gesellschaft, 735 129:429-460.

736 Burg J-P, Van Den Driessche J, Brun J-P (1994) Syn- to post-thickening extension in the 737 Variscan Belt of Western Europe: Modes and structural consequences. Géologie de la France $738 \quad 3: 33-51$.

739 Cassard D, Feybesse J-L, Lescuyer J-L (1993) Variscan crustal thickening, extension and late 740 overstacking during the Naumrian-Westphalian in the western Montagne Noire.

741 Tectonophycics 222: 33-53

742 Cathelineau M, Boiron M-C, Holliger P, Poty B (1990). Metallogenesis of the French part of 743 the Variscan orogen. Part II: Time-space relationships between U, Au and Sn-W ore 744 deposition and geodynamic events — mineralogical and U-Pb data. Tectonophysics 177:5974579.

746 Charles N, Faure M, Chen Y (2009) The Montagne Noire migmatitic dome emplacement 747 (French Massif Central): new insights from petrofabric and AMS studies. Journal of 748 Structural Geology 31:1423-1440.

749 Cocherie A, Legendre O, Peucat J-J, Kouamelan AN (1998) Geochronology of polygenetic 750 monazites constrained by in situ electron microprobe Th-U-total lead determination; 751 implications for lead behaviour in monazite. Geochimica Cosmochimica Acta 62:2475 7522497.

753 Cocherie A, Albarède F (2001) An improved U-Th-Pb age calculation for electron 754 microprobe dating of monazite. Geochimica et Cosmochimica Acta 65:4509-4522.

755 Didier A, Bosse V, Boulvais P, Bouloton J, Paquette J-L, Montel J-M, Devidal J-L (2013)

756 Disturbance versus preservation of $\mathrm{U}-\mathrm{Th}-\mathrm{Pb}$ ages in monazite during fluid-rock interaction:

757 textural, chemical and isotopic in situ study in microgranites (Velay Dome, France).

758 Contributions to Mineralogy and Petrology 165:1051-1072

759 Demange M (1982) Etude géologique du massif de l'Agout, Montagne Noire, France, Thèse 760 d'Etat, University Paris 6, 1050 pp

761 Demange M, Guérangé-Lozes J, Guérangé B (1995) Notice explicative, Carte géol. France 762 (1/50 000), feuille Lacaune (987). Orléans, BRGM, 153 pp 
763 Doublier M P, Potel S, Wemmer K (2015) The tectono-metamorphic evolution of the very 764 low-grade hangingwall constrains two-stage gneiss dome formation in the Montagne Noire 765 (Southern France). Journal of metamorphic Geology 33: 71-89

766 Echtler H (1990) Geometry and kinematics of recumbent folding and low-angle detachment 767 in the Pardailhan nappe (Montagne Noire, Southern French Massif Central). Tectonophysics 768 177: 109-123

769 Echtler H, Malavieille M (1990) Extensional tectonics, basement uplift and Stephano-Permian 770 collapse basin in a late Variscan metamorphic core complex (Montagne Noire, Southern 771 Massif Central). Tectonophysics 177: 125-138

772 Faure M, Cottereau N (1988) Données cinématiques sur la mise en place du dôme 773 migmatitique carbonifère moyen de la zone axiale de la Montagne noire (Massif central 774 français). Comptes rendus de l'Académie des Sciences 307: 1787-1794

775 Faure M, Cocherie A, Bé Mézème E, Charles N, Rossi P (2010) Middle Carboniferous crustal 776 melting in the Variscan Belt: New insights from $\mathrm{U}-\mathrm{Th}-\mathrm{Pb} \mathrm{b}_{\text {tot. }}$ monazite and $\mathrm{U}-\mathrm{Pb}$ zircon ages of 777 the Montagne Noire Axial Zone (southern French Massif Central). Gondwana Research $778 \quad 18: 653-673$.

779 Foster G, Kinny P, Vance D, Prince C, Harris N (2000) The significance of monazite U-Th$780 \mathrm{~Pb}$ age data in metamorphic assemblages; a combined study of monazite and garnet 781 chronometry. Earth and Planetary Science Letters 181:327-340.

782 Franke W, Doublier MP, Klama K, Potel S, Wemmer K (2011) Hot metamorphic core 783 complex in a cold foreland. International Journal of Earth Sciences 100: 753-785

784 Gardés E, Montel J-M, Seydoux-Guillaume A-M, Wirth R (2007) Pb diffusion in monazite: 785 New constraints from the experimental study of $\mathrm{Pb}^{2+} \Leftrightarrow \mathrm{Ca}^{2+}$ interdiffusion. Geochimica et 786 Cosmochimica Acta 71:4036-4043.

787 Gasquet D, Bertrand J-M, Paquette J-L, Lehmann J, Ratzov G, De Ascenção Guedes R, 788 Tiepolo M, Boullier AM, Scaillet S, Nomade S (2010) Miocene to Messinian deformation and 789 hydrothermalism in the Lauzière Massif (French Western Alps): New U-Th-Pb and Argon 790 ages. Bulletin de la Société Géologique de France 181:227-241.

791 Hollister LS (1993) The role of melt in the uplift and exhumation of orogenic belts. Chem. 792 Geol. 108:31-48 
Holtz F, Johannes W (1994) Maximum and minimum water contents of granitic melts:

794 implications for chemical and physical properties of ascending magmas. Lithos 32:149-159

795 Holtz F, Johannes W, Tamic N, Behrens H (2001) Maximum and minimum water contents of granitic melts generated in the crust: reevaluation and implications. Lithos 56:1-14

797

798

799

800

801

802

803

804

805

806

807

808

809

810

811

812

813

814

815

816

817

818

819

820

821

822

Hurai V, Paquette J-L, Huraiová M, Konečný P (2010) U-Th-Pb geochronology of zircon and monazite from syenite and pincinite xenoliths in Pliocene alkali basalts of the intra-

Carpathian back-arc basin. Journal of Volcanology and Geothermal Research 198:275-287.

Jackson SE, Pearson NJ, Griffin WL, Belousova EA (2004) The application of laser ablationinductively coupled plasma-mass spectrometry to in situ U-Pb zircon geochronology.

Chemical Geology 211:47-69.

Jercinovic MJ, Williams ML (2005) Analytical perils (and progress) in electron microprobe trace elements analysis applied to geochronology: Background, interferences and beam irradiation effects. American Mineralogist 90:526-546.

Jourdan F, Renne PR (2007) Age calibration of the Fish Canyon sanidine ${ }^{40} \mathrm{Ar} /{ }^{39} \mathrm{Ar}$ dating standard using primary K-Ar standards. Geochimimica Cosmochimica Acta 71:387-402.

Jourdan F, Verati C, Féraud G (2006) Intercalibration of the $\mathrm{Hb} 3 \mathrm{gr}{ }^{40} \mathrm{Ar} /{ }^{39} \mathrm{Ar}$ dating standard. Chemical Geology 231:77-189.

Kelsey DE, Clark C, Hand M (2008) Thermobarometric modelling of zircon and monazite growth in melt-bearing systems: examples using model metapelitic and metapsammitic granulites. Journal of Metamorphic Geology 26:199-212.

Ludwig KR (1998) On the treatment of concordant uranium-lead ages. Geochimica et Cosmochimica Acta 62:665-676.

Ludwig KR (2001) User's manual for Isoplot/Ex Version 2.49, a geochronological toolkit for Microsoft Excel. Spec Publ., 1a. Berkeley Geochronological Center, Berkeley, USA.

Maluski H, Costa S, Echtler H (1991) Late Variscan tectonic evolution by thinning of earlier thickened crust. An ${ }^{40} \mathrm{Ar}^{39}{ }^{39} \mathrm{Ar}$ study of the Montagne Noire, southern Massif Central, France. Lithos 26:287-304.

Matte P, Lancelot J, Mattauer (1998) The Montagne Noire Axial Zone is not an extensional metamorphic core complex but a compressional post-nappe anticline with an anatectic core. 
Ménard G, Molnar P (1988) Collapse of a Hercynian Tibetan Plateau into a late Paleozoic European Basin and Range province. Nature 334:235-237.

Montel J-M, Marignac C, Barbey P, Pichavant M (1992) Thermobarometry and granite genesis: the Hercynian low-P high-T Velay anactectic Dome (French Massif Central). Journal of Metamorphic Geology 10:1-15.

Montel J, Foret S, Veschambre M, Nicollet C, Provost A (1996) Electron microprobe dating of monazite. Chemical Geology 131:37-53.

Mougeot R, Respaut J-P, Ledru P, Marignac C (1997) U-Pb geochronology on accessory minerals of the Velay anatectic Dome (French Massif Central). European Journal of Mineralogy 9:141-156.

Paquette J-L, Tiepolo M (2007) High resolution (5 $\mu \mathrm{m}) \mathrm{U}-\mathrm{Th}-\mathrm{Pb}$ isotopes dating of monazite with excimer laser ablation (ELA)-ICPMS. Chemical Geology 240:222-237.

Pitra P, Ballèvre M, Ruffet G (2010) Inverted metamorphic field gradient towards a Variscan suture zone (Champtoceaux Complex, Armorican Massif, France). Journal of Metamorphic Geology 28:183-208.

Pitra P, Poujol M, Van Den Driessche J, Poilvet J-C, Paquette J-L (2012) Early Permian extensional shearing of an Ordovician granite: The Saint-Eutrope ,"C/S-like" orthogneiss (Montagne Noire, French Massif Central). Comptes Rendus Geoscience 344:377-384.

Pochat S, Van Den Driessche J (2011) Filling sequence in Late Paleozoic continental basins; A chimera of climate change. A new light shed given by the Graissessac-Lodève basin (SE France). Palaeogeography, Palaeoclimatology, Palaeoecology 302:170-186.

Poilvet J-C, Poujol M, Pitra P, Van Den Driessche J, Paquett, J-L (2011) The Montalet granite, Montagne Noire, France: An early Permian syn-extensional pluton as evidenced by new U-Th-Pb data on zircon and monazite. Comptes Rendus Geoscience 343:454-461.

Poitrasson F, Chenery S, Shepherd TJ (2000) Electron microprobe and LA-ICP-MS study of monazite hydrothermal alteration: Implications for $\mathrm{U}-\mathrm{Th}-\mathrm{Pb}$ geochronology and nuclear ceramics. Geochimica and Cosmochimica Acta 64:3283-3297.

Pommier A, Cocherie A, Legendre O (2002) EPMA Dating User's manual: Age calculation from electron probe microanalyser measurements of $\mathrm{U}-\mathrm{Th}-\mathrm{Pb}$. BRGM, $9 \mathrm{pp}$. 
852

853

854

855

856

857

858

859

860

861

862

863

864

865

866

867

868

869

870

871

872

873

874

875

876

877

878

879

880

881

Rabin M, Trap P, Carry N., Fréville K., Centi-Tok B, Lobjoie C, Goncalves P, Marquer D (2015) Strain partitioning along the anatectic front in the Variscan Montagne Noire massif (southern French Massif Central). Tectonics:34 :doi:10.1002/2014TC003790.

Renne PR, Balco G, Ludwig RL, Mundil R, Min K (2011) Response to the comment by W.H. Schwarz et al. on "Joint determination of (40)K decay constants and (40)Ar*/(40)K for the Fish Canyon sanidine standard, and improved accuracy for (40)Ar/(39)Ar geochronology" by PR Renne et al. (2010). Geochimica et Cosmochimica Acta 75:5097-5100.

Renne PR, Mundil R, Balco G, Min K, Ludwig RL (2010) Joint determination of ${ }^{40} \mathrm{~K}$ decay constants and ${ }^{40} \mathrm{Ar} *{ }^{40} \mathrm{~K}$ for the Fish Canyon sanidine standard, and improved accuracy for ${ }^{40} \mathrm{Ar} /{ }^{39} \mathrm{Ar}$ geochronology. Geochimica et Cosmochimica Acta 74:5349-5367.

Rey PF, Teyssier C, Whitney DL (2011) Viscous collision in channel explains double domes in metamorphic core complexes. Geology 39: 387-390

Roddick JC (1983) High precision intercalibration of ${ }^{40} \mathrm{Ar} /{ }^{39} \mathrm{Ar}$ standards. Geochimica et Cosmochimica Acta 47:887-898.

Roger F, Respaut J-P, Brunel M, Matte P, Paquette J-L (2004) U-Pb dating of Augen orthogneisses from the Axial Zone of the Montagne Noire (Southern Massif Central): new witness of Ordovician magmatism into the Variscan Belt. Comptes Rendus Geoscience 336:19-28.

Roger F, Teyssier C, Respaut J-P, Rey PF, Jolivet M, Whitney DL, Paquette J-L, Brunel M (2015) Timing of formation and exhumation of the Montagne Noire double dome, French Massif Central. Tectonophysics 640-641:53-69

Rubatto D, Williams IS, Buick IS (2001 Zircon and monazite response to prograde metamorphism in the Reynolds Range, central Australia. Contributions to Mineralogy and Petrology 140:458-468.

Ruffet G, Féraud G, Amouric M (1991) Comparison of ${ }^{40} \mathrm{Ar} /{ }^{39} \mathrm{Ar}$ conventional and laser dating of biotites fram the North Trégor Batholith. Geochimica et Cosmochimica Acta 55:1675-1688. Ruffet G, Féraud G, Ballèvre M, Kiénast JR (1995) Plateau ages and excess argon on phengites: $\mathrm{a}^{40} \mathrm{Ar} /{ }^{39} \mathrm{Ar}$ laser probe study of alpine micas (Sesia zone). Chemical Geology 121:327-343.

Seydoux-Guillaume A-M, Paquette J-L, Wiedenbeck M, Montel J-M, Heinrich W (2002) Experimental resetting of the U-Th-Pb systems in monazite. Chemical Geology 191:165-181. 
882 Soula JC, Debat P, Brusset S, Bessière G, Christophoul F, Déramond J (2001) Thrust-related, 883 diapiric, and extensional doming in a frontal orogenic wedge: exemple of the Montagne noire, 884 Southern French Hercynian Belts. Journal of Structural Geology 23: 1677-1699

885 Spear FS, Pyle JM (2010) Theoretical modeling of monazite growth in a low-Ca metapelite. 886 Chemical Geology 273:111-119.

887 Spear FS, Pyle JM, Cherniak D (2009) Limitations of chemical dating of monazite, Chemical 888 Geology 266:218-230.

889 Taner MF, Martin RF (1993) Significance of dumortierite in an aluminosilicate-rich alteration 890 zone, Louvicourt, Quebec. Canadian Mineralogist 31:137-146.

891 Tartèse R, Ruffet G, Poujol M, Boulvais P, Ireland TR (2011) Simultaneous resetting of the 892 muscovite K-Ar and monazite U-Pb geochronometers: a story of fluids. Terra Nova 23:390893398.

894 Tartèse R, Boulvais P, Poujol M, Chevalier T, Paquette J-L, Ireland TR, Deloule E (2012)

895 Mylonites of the South Armorican Shear Zone: Insights for crustal-scale fluid flow and water896 rock interaction processes. Journal of Geodynamics 56-57:86-107.

897 Thompson AB (2001) Clockwise P-T paths for crustal melting and $\mathrm{H}_{2} \mathrm{O}$ recycling in granite 898 source regions and migmatite terrains. Lithos 56:33-45

899 Turner G, Huneke JC, Podosek FA, Wasserburg GJ (1971) ${ }^{40} \mathrm{Ar} /{ }^{39} \mathrm{Ar}$ ages and cosmic ray 900 exposure age of Apollo 14 samples. Earth and Planetary Science Letters 12:19-35.

901 Van Den Driessche J, Brun J-P (1989) Un modèle cinématique de l'extension paléozoïque 902 supérieur dans le sud du Massif Central. Comptes Rendus de l'Académie des Sciences série 2 903 309:1607-1613.

904 Van Den Driessche J, Brun J-P (1992) Tectonic evolution of the Montagne Noire (French 905 Massif Central): a model of extensional dome. Geodinamica Acta 5:85-99.

906 Van Den Driessche J, Pitra P (2012) Viscous collision channel explains double dome in 907 metamorphic core complexes: Comment. Geology 40: e279

908 Velichkin VI, Vlasov BP (2011) Domal structures and hydrothermal uranium deposits of the 909 Erzgebirge, Saxony, Germany. Geol. Ore Depos. 53:74-83. 
910 Wiedenbeck M, Allé P, Corfu F, Griffin WL, Meier M, Oberli F, von Quadt A, Roddick JC, 911 Spiegel W (1995) Three natural zircon standards for U-Th-Pb, Lu-Hf, trace element and 912 REE analyses. Geostandard Newsletter 19:1-23.

913 Williams ML, Jercinovic MJ, Harlov DE, Budzyn Hetherington CJ (2011) Resetting monazite 914 ages during fluid-related alteration. Chemical Geology 283:218-225.

915 
918 Figure 1. Structural map of the southern French Massif Central (MC) showing the

919 relationships between the Montagne Noire gneiss dome, the Stephanian-Permian basins, and

920 the Variscan thrusts and nappes (modified after Brun and Van Den Driessche, 1994). 7, 8:

921 locations of the samples ES7 and ES8, respectively, Af: St. Affrique basin, G: Graissessac

922 basin, L: Laouzas granite, Lo: Lodève basin P: Col de Picotalen (location of the sample of the

923 Montalet syntectonic leucogranite, ES5, Poilvet et al. 2011), V: Vialais granite.

924 Inset shows the location of the study area within the European Variscan belt (modified from

925 Pitra et al. 2010). A - Alps, AM - Armorican Massif, BM - Bohemian Massif, MC - Massif

926 Central. B - Teplá-Barrandian, Mo - Moldanubian, ST - Saxothuringian, RH -

927 Rhenohercynian. L: Lyon; M: Montpellier; R: Rennes.

929 Figure 2. (a) Outcrop photograph of the Laouzas granite (ES7). Dark spots are clusters of 930 cordierite, the elongated object in the lower central part is a biotite-rich schliere. (b-c)

931 Microphotographs of the granite. Note the presence of subhedral, partly altered crystals of 932 plagioclase (pl) and K-feldspar (kfs), partly pinitised crystals of cordierite (cd), and late 933 crystals of dumoritierite (dum), andalusite (and) and muscovite (mu), and the clear rim around 934 altered plagioclase core. (d) Outcrop photograph of the banded La Salvetat migmatite (ES8).

935 Rare garnet crystals are shown by arrows. (e-f) Microphotographs of the migmatite

936 leucosome. Interstitial brown-blue tourmaline is located between subhedral, partly altered 937 crystals of feldspars and anhedral quartz (e). Plagioclase crystals are partly replaced by 938 clinozoisite (tiny high-relief crystals), biotite contains prehnite (prh) and/or clay minerals 939 parallel to the (001) cleavage; late muscovite is also present (f).

Figure 3: Cathodoluminescence images of some of the zircon grains dated in this study: A:

942 Laouzas granite; B and C: La Salvetat migmatite. The white circle represents the spot analysis 943 and the number corresponds to the ${ }^{207} \mathrm{~Pb} /{ }^{206} \mathrm{~Pb}$ age obtained. $\mathrm{Zr}$ number corresponds to the 944 grain number in Table 1.

946 Figure 4: Summary of the geochronological results. In all diagram, $N$ refers to the number of 947 analyses. Grey ellipses correspond to the data used to calculate the concordia ages. A and C: 948 Tera-Wasserburg ${ }^{207} \mathrm{~Pb} /{ }^{206} \mathrm{~Pb}$ versus ${ }^{238} \mathrm{U} /{ }^{206} \mathrm{~Pb}$ concordia diagram for the zircon grains 949 analyzed in the Laouzas granite (A) and the La Salvetat migmatite (C). B and $\mathrm{D}:{ }^{206} \mathrm{~Pb} /{ }^{238} \mathrm{U}$ 
950 versus ${ }^{208} \mathrm{~Pb} /{ }^{232} \mathrm{Th}$ diagram for the monazite analyzed in the Laouzas granite (B) and the La 951 Salvetat migmatite (D). E: Relative probability plot of ${ }^{207} \mathrm{~Pb} /{ }^{206} \mathrm{~Pb}$ dates for all the more than $95290 \%$ concordant zircon grains obtained in this study. F: Relative probability plots for all the 953 monazite ${ }^{206} \mathrm{~Pb} /{ }^{238} \mathrm{U}$ dates obtained in this study. G: Relative probability plots for all the 954 monazite ${ }^{208} \mathrm{~Pb} /{ }^{232} \mathrm{Th}$ dates obtained in this study. $\mathrm{H}:{ }^{40} \mathrm{Ar}-{ }^{39} \mathrm{Ar}$ spectra of muscovite from 955 samples ES5, ES7 and ES8. The error bars for each temperature steps are at the $1 \sigma$ level. The 956 errors in the J-values are not included. Plateau age error is at the $2 \sigma$ level.

958 Figure 5: Top picture: Backscattered electron image of the Type 1 monazite from sample ES7 959 (i.e. ca. $318 \mathrm{Ma}$ ). White circle represents the spot analysis and has a diameter of 7 microns. 960 Date refers to the ${ }^{208} \mathrm{~Pb} /{ }^{232} \mathrm{Th}$ individual date. $\mathrm{M}$ number refers to the grain number in Table 2.

961 White square corresponds to the location of the NanoSIMS elemental images ( 8 bottom 962 pictures).

964 Figure 6: Top picture: Backscattered electron image of the Type 2 monazite from sample ES7 965 (i.e. ca. $294 \mathrm{Ma}$ ). White circle represents the spot analysis and has a diameter of 7 microns.

966 Date refers to the ${ }^{208} \mathrm{~Pb} /{ }^{232} \mathrm{Th}$ individual date. M number refers to the grain number in Table 2.

967 White square corresponds to the location of the NanoSIMS elemental images ( 8 bottom 968 pictures).

970 Figure 7: Top picture: Backscattered electron image of the first group of monazite grains (i.e. 971 ca. $319 \mathrm{Ma}$ ) from sample ES8. White circle represents the spot analysis and has a diameter of 9727 microns. Date refers to the ${ }^{208} \mathrm{~Pb} /{ }^{232} \mathrm{Th}$ date. M number refers to the grain number in Table

973 2. White square corresponds to the location of the NanoSIMS elemental images ( 8 bottom 974 pictures).

976 Figure 8: Top picture: Backscattered electron image of the second group of monazite grains 977 (i.e. ca. $298 \mathrm{Ma}$ ) from sample ES8. White circle represents the spot analysis and has a 978 diameter of 7 microns. Date refers to the ${ }^{208} \mathrm{~Pb} /{ }^{232} \mathrm{Th}$ date. $\mathrm{M}$ number refers to the grain 979 number in Table 2. White square corresponds to the location of the NanoSIMS elemental 980 images ( 8 bottom pictures).

982 Figure 9: $\mathrm{Th} / \mathrm{Pb}$ versus $\mathrm{U} / \mathrm{Pb}$ plots using data for the monazite grains from the Montalet 983 granite (A; from Poilvet et al. 2011), the Laouzas granite (B) and the La Salvetat migmatite 
984 (C). For all the diagrams, ages obtained by LA-ICP-MS (this study) are given for comparison. $985 n$ refers to the number of analyses plotted in the diagrams. For more explanation on these 986 plots see Cocherie and Albarède (2001).

988 Figure 10: Weighted-histogram representation of the data acquired in this study for sample 989 ES7 following the statistical 1D data treatment of Montel et al (1996) for EPMA dating. For 990 more explanation on this plot see Montel et al. (1996).

991

992 Table 1: U-Th-Pb LA-ICP-MS data for the zircon grains from sample ES7 and ES8. Errors 993 are reported at 1 sigma.

994

995 Table 2: U-Th-Pb LA-ICP-MS data for the monazite grains from sample ES7 and ES8. Errors 996 are reported at 1 sigma. 


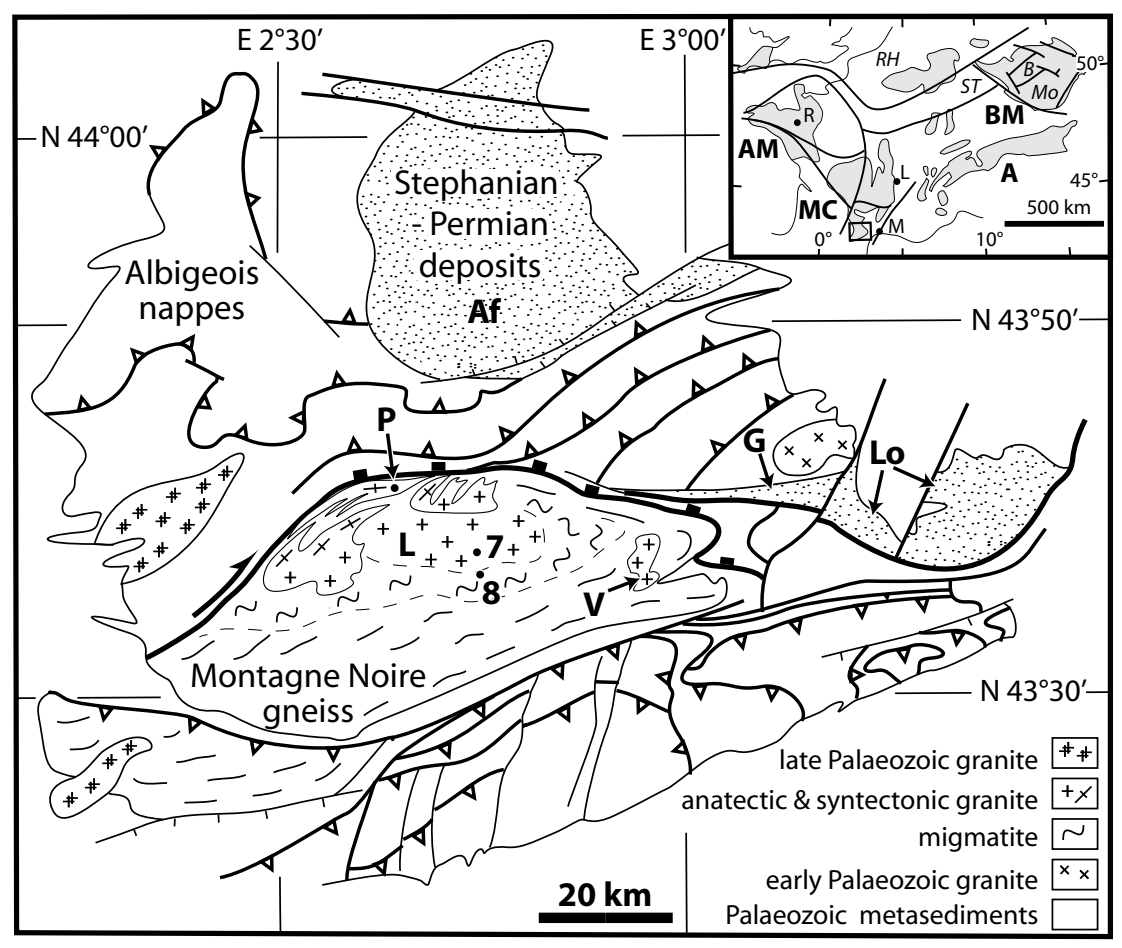

Poujol et al.: Fig. 1 

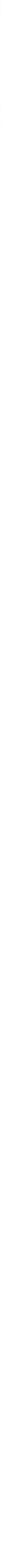


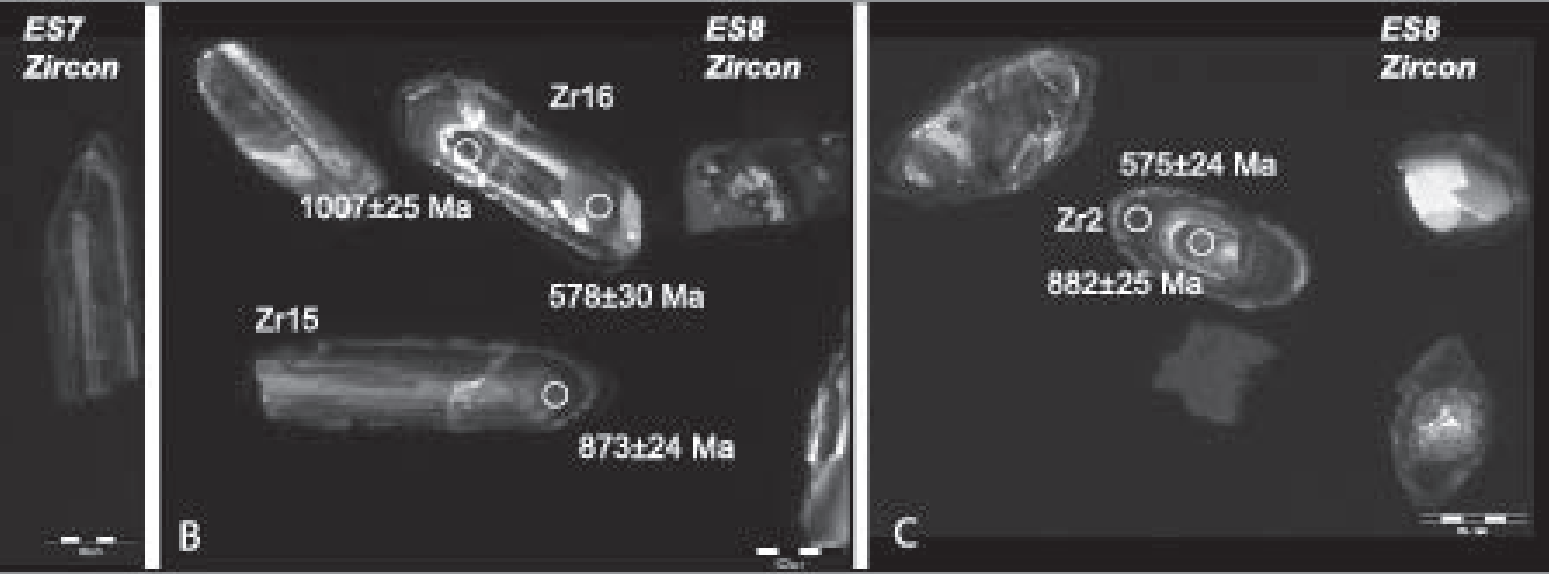

Figure 3: Poujol et al. 
Poujol et al., Figure 4
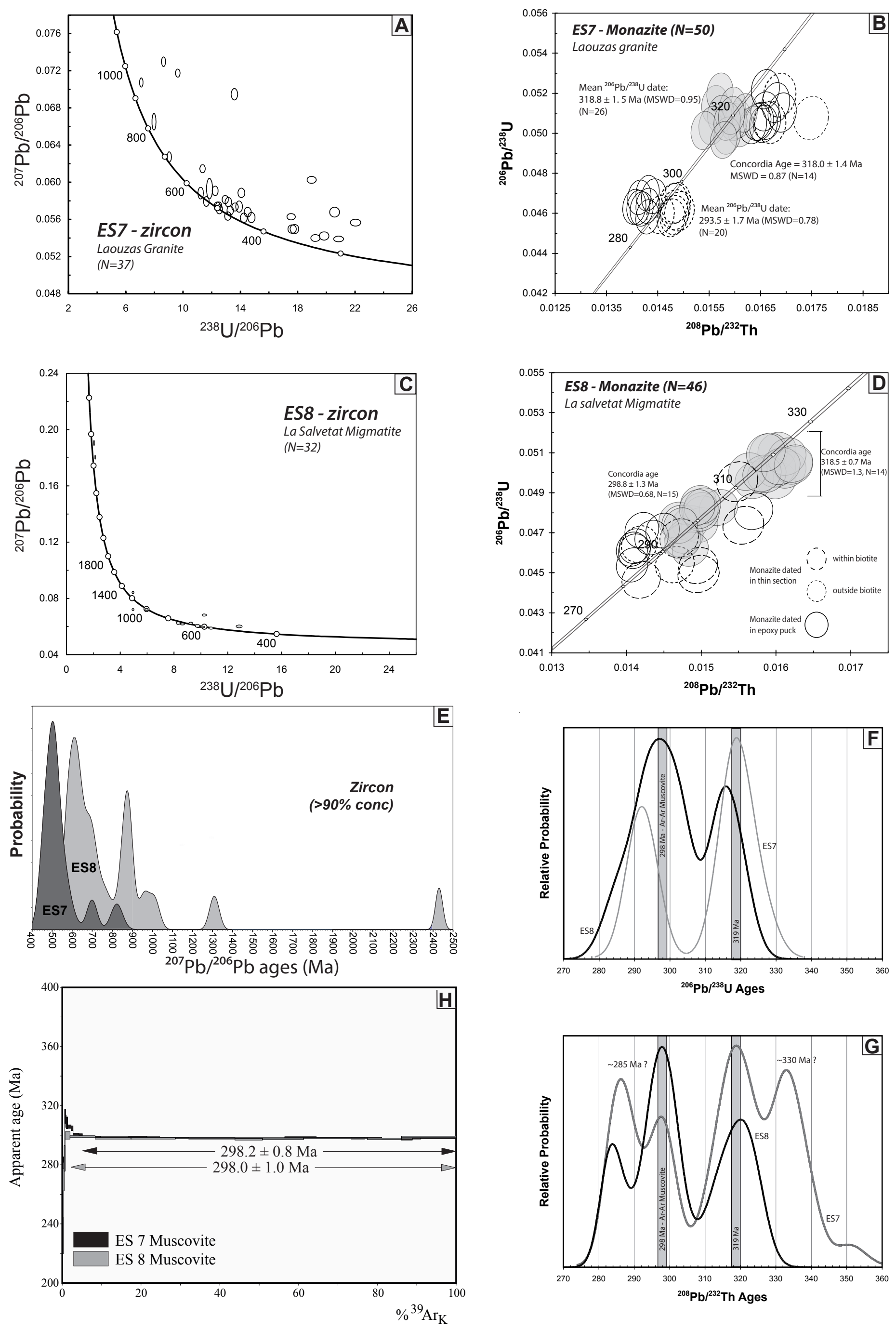

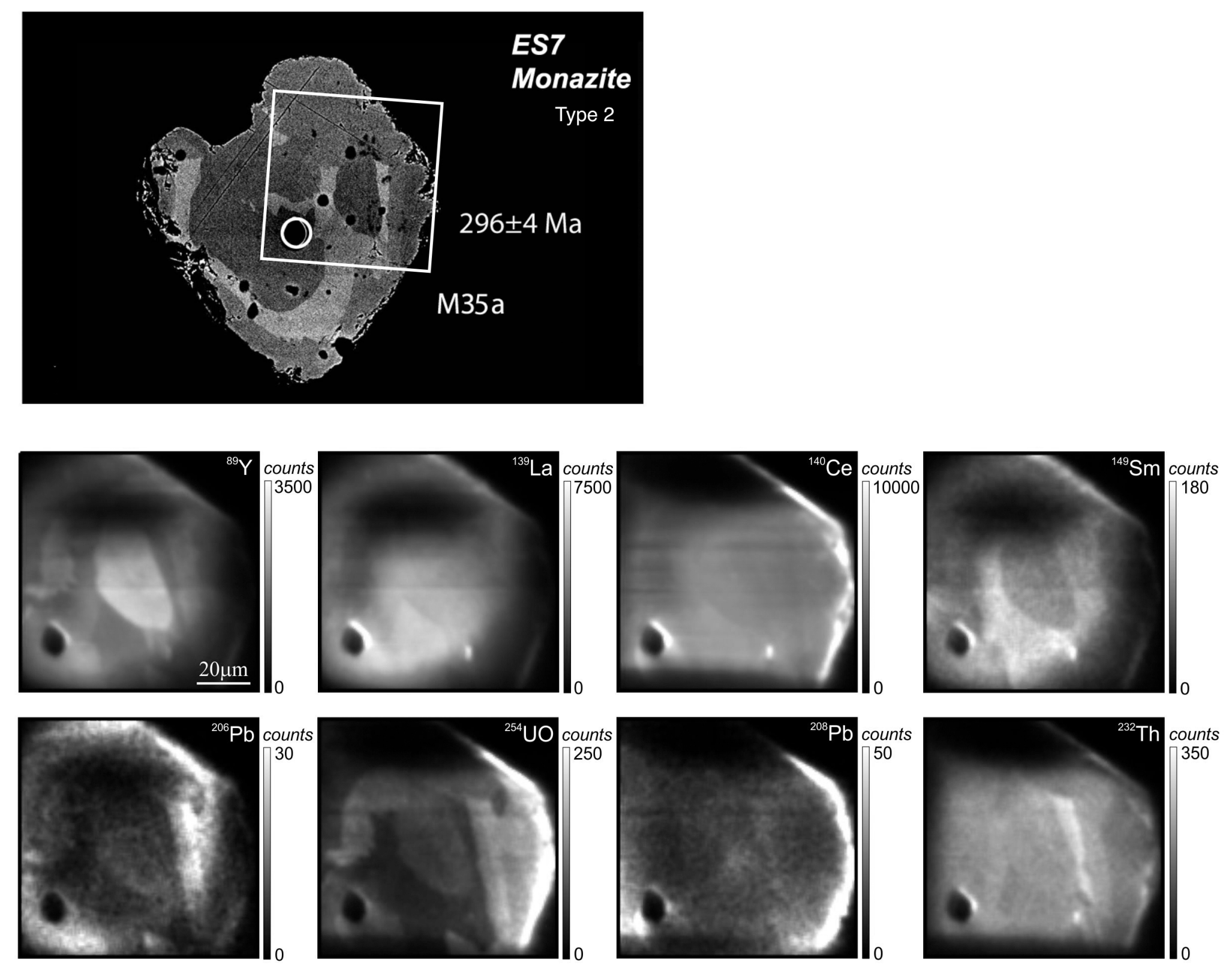

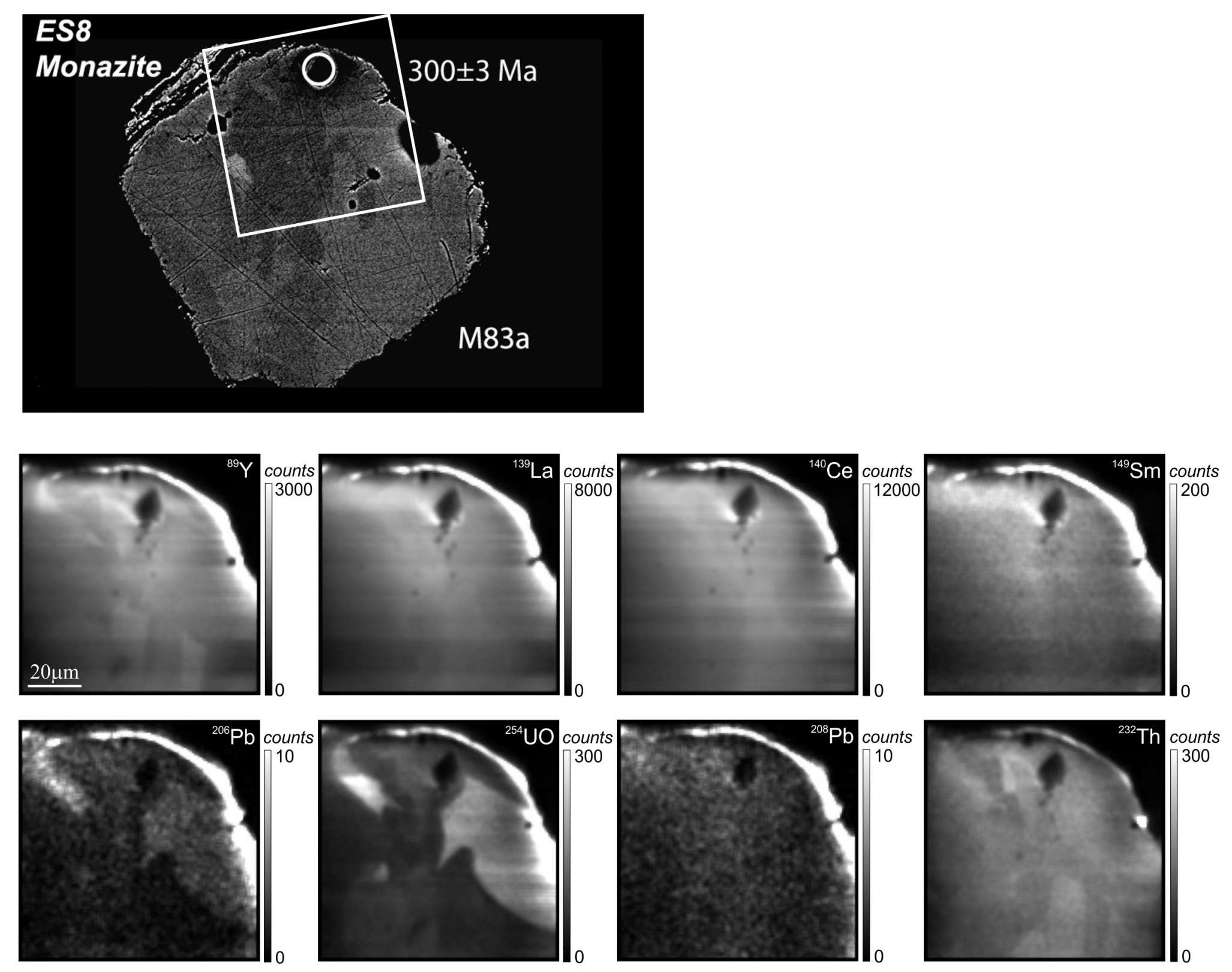
Figure 10: Poujol et al.

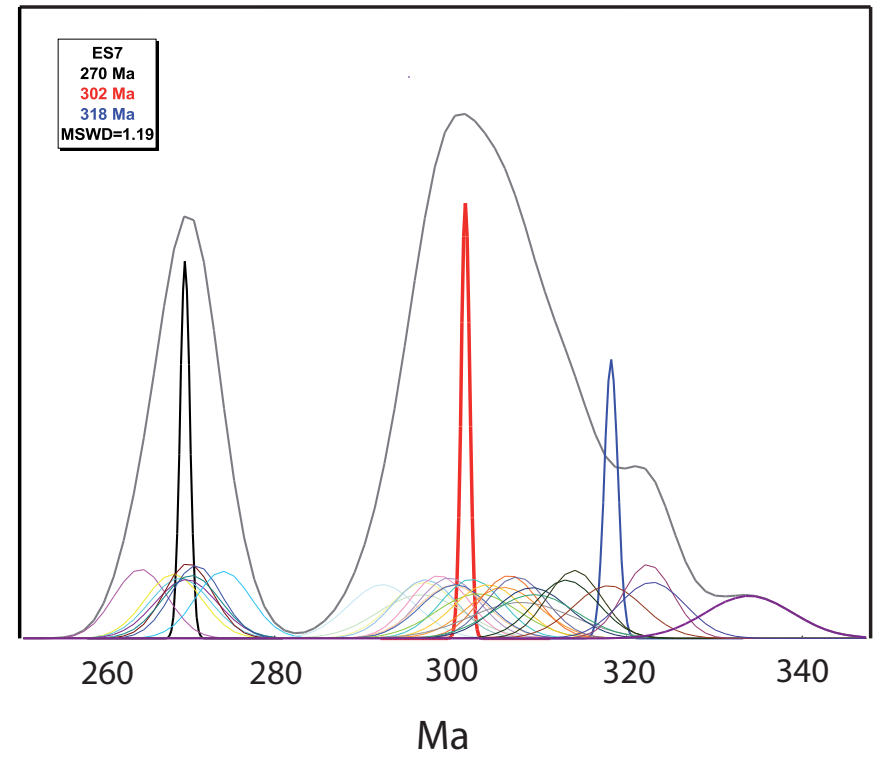




\begin{tabular}{|c|c|c|c|c|c|c|c|c|c|c|c|c|c|c|c|}
\hline \multirow{2}{*}{$\begin{array}{l}\text { grain } \\
\text { (zircon) }\end{array}$} & \multirow{2}{*}{$\begin{array}{c}{[\mathrm{Pb}]} \\
(\mathrm{ppm})\end{array}$} & \multirow{2}{*}{$\begin{array}{c}{[\mathrm{U}]} \\
(\mathrm{ppm})\end{array}$} & \multirow[t]{2}{*}{$\mathrm{Th} / \mathrm{U}$} & \multirow{2}{*}{$\begin{array}{c}{ }^{207} \mathrm{~Pb} / \\
{ }^{235} \mathrm{U}\end{array}$} & \multirow{2}{*}{$\begin{array}{c} \pm \\
1 \sigma\end{array}$} & \multirow{2}{*}{$\begin{array}{l}{ }^{206} \mathrm{~Pb} / \\
{ }^{238} \mathrm{U}\end{array}$} & \multirow{2}{*}{$\begin{array}{c} \pm \\
1 \sigma\end{array}$} & \multirow{2}{*}{$\begin{array}{l}{ }^{207} \mathrm{~Pb} / \\
{ }^{206} \mathrm{~Pb}\end{array}$} & \multirow{2}{*}{$\begin{array}{c} \pm \\
1 \sigma\end{array}$} & \multirow[t]{2}{*}{ Rho } & \multicolumn{4}{|c|}{ Ages } & \multirow{2}{*}{$\begin{array}{r}\text { Conc. } \\
(\%)\end{array}$} \\
\hline & & & & & & & & & & & $\begin{array}{l}{ }^{207} \mathrm{~Pb} / \\
{ }^{235} \mathrm{U}\end{array}$ & $\begin{array}{l}{ }^{206} \mathrm{~Pb} / \\
{ }^{238} \mathrm{U}\end{array}$ & $\begin{array}{l}{ }^{207} \mathrm{~Pb} / \\
{ }^{206} \mathrm{~Pb}\end{array}$ & $\begin{array}{l} \pm \\
1 \\
\sigma \\
\end{array}$ & \\
\hline \multicolumn{16}{|c|}{ ES 7 Laouzas Granite } \\
\hline $1.2 \mathrm{c}$ & 31 & 509 & 0.19 & 0.705 & 0.009 & 0.0736 & 0.0008 & 0.0695 & 0.0008 & 0.88 & 542 & 458 & 913 & 25 & 50 \\
\hline $2.1 \mathrm{c}$ & 39 & 376 & 0.43 & 1.166 & 0.014 & 0.1158 & 0.0013 & 0.0730 & 0.0008 & 0.92 & 785 & 707 & 1014 & 23 & 70 \\
\hline $2.2 \mathrm{c}$ & 104 & 2810 & 0.01 & 0.356 & 0.004 & 0.0480 & 0.0005 & 0.0539 & 0.0006 & 0.95 & 310 & 302 & 367 & 25 & 82 \\
\hline $4.1 \mathrm{c}$ & 102 & 988 & 0.85 & 1.028 & 0.012 & 0.1039 & 0.0011 & 0.0718 & 0.0008 & 0.94 & 718 & 637 & 979 & 22 & 65 \\
\hline $4.2 \mathrm{c}$ & 99 & 2374 & 0.02 & 0.438 & 0.005 & 0.0527 & 0.0006 & 0.0603 & 0.0007 & 0.94 & 369 & 331 & 613 & 24 & 54 \\
\hline 6.1c & 10 & 90 & 0.50 & 1.151 & 0.017 & 0.1255 & 0.0014 & 0.0665 & 0.0009 & 0.78 & 778 & 762 & 823 & 29 & 93 \\
\hline $6.2 c$ & 15 & 212 & 0.17 & 0.723 & 0.010 & 0.0891 & 0.0010 & 0.0588 & 0.0008 & 0.84 & 552 & 550 & 561 & 27 & 98 \\
\hline $7.2 \mathrm{c}$ & 73 & 1834 & 0.02 & 0.387 & 0.005 & 0.0520 & 0.0006 & 0.0540 & 0.0006 & 0.92 & 332 & 327 & 371 & 25 & 88 \\
\hline $8.1 \mathrm{c}$ & 62 & 501 & 0.44 & 1.378 & 0.016 & 0.1413 & 0.0016 & 0.0708 & 0.0008 & 0.92 & 880 & 852 & 950 & 23 & 90 \\
\hline $8.2 \mathrm{c}$ & 29 & 317 & 0.20 & 0.958 & 0.012 & 0.1107 & 0.0012 & 0.0627 & 0.0008 & 0.88 & 682 & 677 & 699 & 25 & 97 \\
\hline $10 c$ & 61 & 834 & 0.22 & 0.746 & 0.009 & 0.0880 & 0.0010 & 0.0615 & 0.0007 & 0.92 & 566 & 544 & 655 & 24 & 83 \\
\hline $12.1 \mathrm{c}$ & 19 & 325 & 0.19 & 0.569 & 0.008 & 0.0719 & 0.0008 & 0.0574 & 0.0007 & 0.85 & 457 & 448 & 506 & 28 & 89 \\
\hline $12.2 \mathrm{c}$ & 157 & 4467 & 0.11 & 0.348 & 0.004 & 0.0454 & 0.0005 & 0.0557 & 0.0006 & 0.93 & 303 & 286 & 439 & 24 & 65 \\
\hline $13 c$ & 46 & 1043 & 0.03 & 0.430 & 0.005 & 0.0568 & 0.0006 & 0.0550 & 0.0006 & 0.90 & 364 & 356 & 411 & 26 & 87 \\
\hline $14.2 \mathrm{c}$ & 87 & 2249 & 0.02 & 0.377 & 0.005 & 0.0504 & 0.0006 & 0.0542 & 0.0006 & 0.90 & 325 & 317 & 380 & 26 & 83 \\
\hline $15 c$ & 67 & 1133 & 0.07 & 0.607 & 0.008 & 0.0760 & 0.0009 & 0.0579 & 0.0007 & 0.89 & 481 & 472 & 525 & 26 & 90 \\
\hline $16.2 \mathrm{c}$ & 86 & 1453 & 0.04 & 0.592 & 0.007 & 0.0762 & 0.0009 & 0.0564 & 0.0007 & 0.90 & 472 & 474 & 466 & 26 & 102 \\
\hline $17 c$ & 106 & 1769 & 0.05 & 0.620 & 0.008 & 0.0773 & 0.0009 & 0.0582 & 0.0007 & 0.91 & 490 & 480 & 535 & 26 & 90 \\
\hline $18 \mathrm{c}$ & 75 & 1739 & 0.02 & 0.427 & 0.005 & 0.0563 & 0.0006 & 0.0550 & 0.0007 & 0.88 & 361 & 353 & 411 & 27 & 86 \\
\hline $19 c$ & 117 & 2052 & 0.07 & 0.580 & 0.007 & 0.0734 & 0.0008 & 0.0573 & 0.0007 & 0.91 & 465 & 457 & 504 & 25 & 91 \\
\hline $20 c$ & 72 & 1135 & 0.05 & 0.666 & 0.008 & 0.0817 & 0.0009 & 0.0591 & 0.0007 & 0.89 & 518 & 506 & 570 & 25 & 89 \\
\hline $22 c$ & 74 & 1972 & 0.03 & 0.381 & 0.005 & 0.0486 & 0.0005 & 0.0568 & 0.0007 & 0.87 & 328 & 306 & 483 & 27 & 63 \\
\hline $23 c$ & 99 & 1573 & 0.07 & 0.639 & 0.008 & 0.0808 & 0.0009 & 0.0574 & 0.0007 & 0.90 & 502 & 501 & 507 & 26 & 99 \\
\hline $24 c$ & 102 & 1656 & 0.05 & 0.628 & 0.008 & 0.0798 & 0.0009 & 0.0571 & 0.0007 & 0.90 & 495 & 495 & 495 & 26 & 100 \\
\hline $25 c$ & 112 & 2013 & 0.05 & 0.577 & 0.007 & 0.0711 & 0.0008 & 0.0589 & 0.0007 & 0.89 & 463 & 443 & 562 & 26 & 79 \\
\hline $26 c$ & 94 & 1728 & 0.04 & 0.544 & 0.007 & 0.0702 & 0.0008 & 0.0562 & 0.0007 & 0.88 & 441 & 438 & 459 & 27 & 95 \\
\hline $27 c$ & 133 & 2301 & 0.04 & 0.591 & 0.007 & 0.0753 & 0.0009 & 0.0570 & 0.0007 & 0.89 & 472 & 468 & 490 & 27 & 96 \\
\hline $28 \mathrm{c}$ & 114 & 1701 & 0.08 & 0.687 & 0.009 & 0.0861 & 0.0010 & 0.0579 & 0.0007 & 0.88 & 531 & 532 & 527 & 27 & 101 \\
\hline
\end{tabular}

ES 8 La Salvetat Migmatite

\begin{tabular}{|c|c|c|c|c|c|c|c|c|c|c|c|c|c|c|c|}
\hline $1.1 \mathrm{~d}$ & 33 & 892 & 0.01 & 0.351 & 0.004 & 0.0478 & 0.0005 & 0.0532 & 0.0006 & 0.88 & 305 & 301 & 337 & 27 & 89 \\
\hline $1.2 \mathrm{~d}$ & 18 & 156 & 2.20 & 0.766 & 0.011 & 0.0932 & 0.0011 & 0.0596 & 0.0008 & 0.79 & 578 & 575 & 590 & 30 & 97 \\
\hline $2.1 \mathrm{~d}$ & 27 & 184 & 0.80 & 1.447 & 0.018 & 0.1533 & 0.0017 & 0.0685 & 0.0008 & 0.88 & 909 & 919 & 882 & 25 & 104 \\
\hline $2.2 \mathrm{~d}$ & 82 & 828 & 1.03 & 0.812 & 0.010 & 0.0995 & 0.0011 & 0.0592 & 0.0007 & 0.93 & 604 & 611 & 575 & 24 & 106 \\
\hline $3 d$ & 44 & 497 & 0.33 & 0.867 & 0.011 & 0.1047 & 0.0012 & 0.0601 & 0.0007 & 0.91 & 634 & 642 & 607 & 25 & 106 \\
\hline $4 d$ & 25 & 631 & 0.01 & 0.389 & 0.006 & 0.0504 & 0.0006 & 0.0560 & 0.0009 & 0.69 & 334 & 317 & 451 & 36 & 70 \\
\hline $5 d$ & 52 & 353 & 0.93 & 1.480 & 0.019 & 0.1512 & 0.0017 & 0.0710 & 0.0009 & 0.88 & 922 & 908 & 957 & 25 & 95 \\
\hline $6 d$ & 26 & 341 & 0.29 & 0.753 & 0.010 & 0.0886 & 0.0010 & 0.0616 & 0.0008 & 0.86 & 570 & 547 & 661 & 27 & 83 \\
\hline $7 d$ & 67 & 635 & 1.41 & 0.839 & 0.011 & 0.0983 & 0.0011 & 0.0619 & 0.0008 & 0.86 & 619 & 605 & 670 & 27 & 90 \\
\hline $8 d$ & 61 & 644 & 0.72 & 0.817 & 0.010 & 0.1014 & 0.0011 & 0.0585 & 0.0007 & 0.90 & 607 & 623 & 547 & 26 & 114 \\
\hline $9 d$ & 25 & 194 & 0.99 & 1.141 & 0.016 & 0.1276 & 0.0014 & 0.0648 & 0.0009 & 0.83 & 773 & 774 & 768 & 28 & 101 \\
\hline $10 d$ & 55 & 429 & 0.36 & 1.413 & 0.017 & 0.1496 & 0.0017 & 0.0685 & 0.0008 & 0.91 & 894 & 899 & 884 & 24 & 102 \\
\hline $11 d$ & 10 & 81 & 0.52 & 1.306 & 0.020 & 0.1414 & 0.0016 & 0.0670 & 0.0010 & 0.74 & 848 & 853 & 838 & 32 & 102 \\
\hline $12 d$ & 116 & 764 & 0.11 & 2.616 & 0.032 & 0.1827 & 0.0020 & 0.1039 & 0.0012 & 0.91 & 1305 & 1082 & 1694 & 21 & 64 \\
\hline $13 d$ & 201 & 2497 & 0.17 & 0.830 & 0.010 & 0.0990 & 0.0011 & 0.0608 & 0.0007 & 0.93 & 614 & 608 & 633 & 24 & 96 \\
\hline $14 d$ & 71 & 605 & 0.12 & 1.370 & 0.018 & 0.1463 & 0.0016 & 0.0679 & 0.0008 & 0.88 & 876 & 880 & 866 & 25 & 102 \\
\hline $15 d$ & 89 & 752 & 0.16 & 1.366 & 0.017 & 0.1454 & 0.0016 & 0.0681 & 0.0008 & 0.89 & 875 & 875 & 873 & 24 & 100 \\
\hline $16.1 d$ & 29 & 413 & 0.09 & 0.713 & 0.010 & 0.0872 & 0.0010 & 0.0593 & 0.0008 & 0.78 & 547 & 539 & 578 & 30 & 93 \\
\hline $16.2 d$ & 43 & 172 & 2.04 & 2.044 & 0.027 & 0.2038 & 0.0023 & 0.0728 & 0.0009 & 0.86 & 1130 & 1195 & 1007 & 25 & 119 \\
\hline $17 d$ & 40 & 255 & 0.73 & 1.693 & 0.023 & 0.1685 & 0.0019 & 0.0729 & 0.0010 & 0.83 & 1006 & 1004 & 1010 & 26 & 99 \\
\hline $18 d$ & 59 & 627 & 0.18 & 1.002 & 0.013 & 0.1162 & 0.0013 & 0.0625 & 0.0008 & 0.87 & 705 & 709 & 692 & 26 & 102 \\
\hline $19 d$ & 36 & 516 & 0.53 & 0.653 & 0.010 & 0.0779 & 0.0009 & 0.0608 & 0.0009 & 0.74 & 511 & 484 & 632 & 33 & 77 \\
\hline $20 d$ & 94 & 1132 & 0.29 & 0.824 & 0.011 & 0.0990 & 0.0011 & 0.0604 & 0.0007 & 0.87 & 611 & 608 & 619 & 26 & 98 \\
\hline $21 d$ & 53 & 597 & 0.50 & 0.852 & 0.011 & 0.1020 & 0.0012 & 0.0606 & 0.0008 & 0.87 & 626 & 626 & 627 & 27 & 100 \\
\hline $22 d$ & 295 & 653 & 0.48 & 11.792 & 0.149 & 0.4746 & 0.0053 & 0.1802 & 0.0022 & 0.89 & 2588 & 2504 & 2655 & 20 & 94 \\
\hline $23.1 d$ & 10 & 98 & 0.26 & 1.049 & 0.016 & 0.1205 & 0.0014 & 0.0631 & 0.0010 & 0.75 & 728 & 734 & 713 & 32 & 103 \\
\hline $23.2 \mathrm{~d}$ & 19 & 215 & 0.22 & 0.942 & 0.014 & 0.1084 & 0.0012 & 0.0630 & 0.0009 & 0.78 & 674 & 663 & 709 & 30 & 94 \\
\hline $24 d$ & 93 & 1001 & 0.69 & 0.927 & 0.012 & 0.0977 & 0.0011 & 0.0688 & 0.0009 & 0.84 & 666 & 601 & 894 & 26 & 67 \\
\hline $25 d$ & 31 & 352 & 0.69 & 0.764 & 0.011 & 0.0930 & 0.0011 & 0.0596 & 0.0008 & 0.81 & 576 & 573 & 588 & 29 & 98 \\
\hline $26 d$ & 113 & 653 & 0.28 & 2.378 & 0.031 & 0.2036 & 0.0023 & 0.0847 & 0.0011 & 0.86 & 1236 & 1195 & 1309 & 24 & 91 \\
\hline $27 d$ & 176 & 360 & 0.63 & 13.005 & 0.171 & 0.4959 & 0.0056 & 0.1902 & 0.0024 & 0.86 & 2680 & 2596 & 2744 & 20 & 95 \\
\hline $28 d$ & 13 & 138 & 0.53 & 0.867 & 0.014 & 0.1026 & 0.0012 & 0.0613 & 0.0010 & 0.73 & 634 & 630 & 649 & 33 & 97 \\
\hline
\end{tabular}




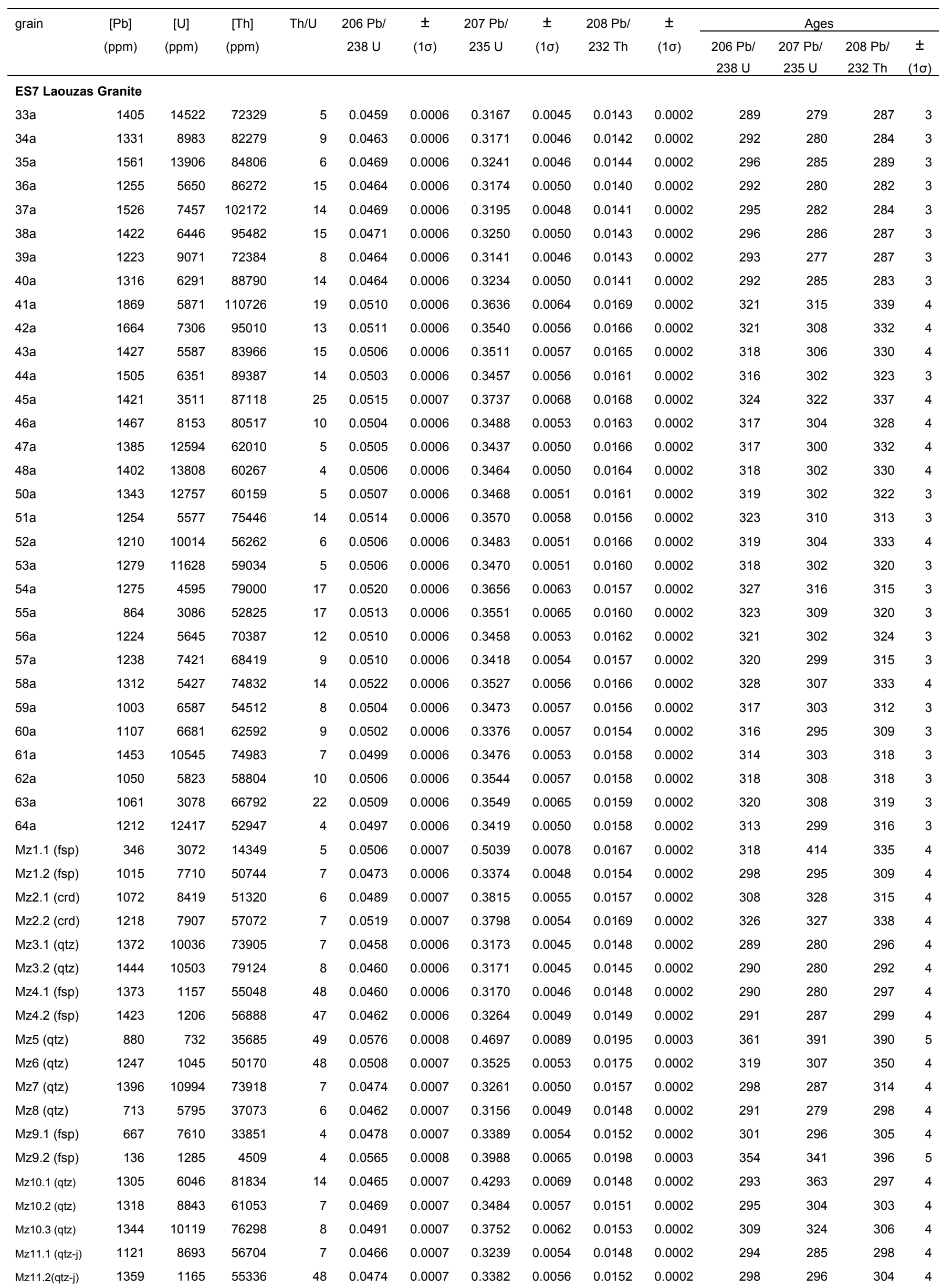




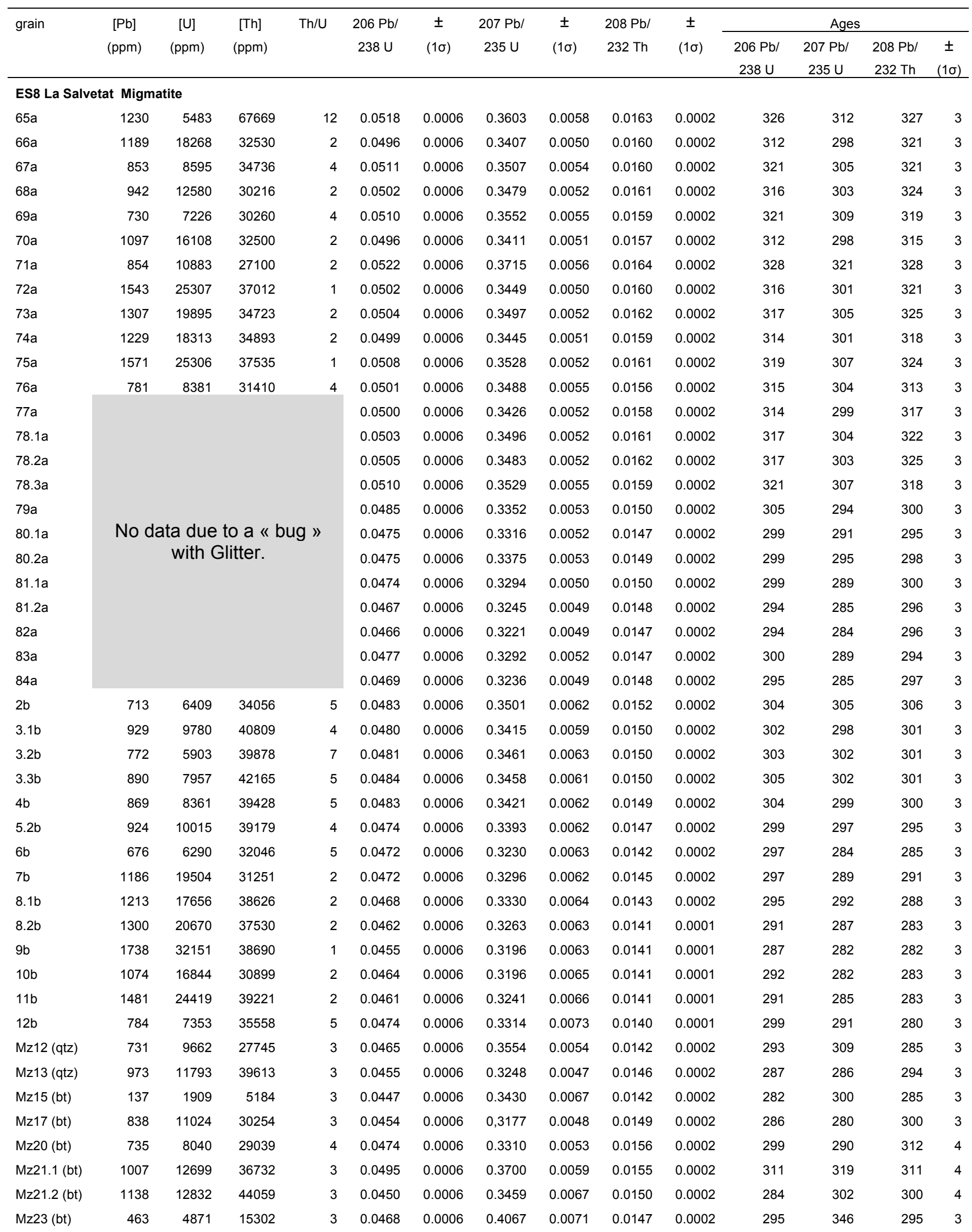

